dr hab. inż. Jarosław Prońko, prof. UJK ${ }^{1}$

st. bryg. w st. sp. mgr inż. Jan Kielin ${ }^{2}$

mgr Beata Wojtasiak ${ }^{2}$

Przyjęty/Accepted/Принята: 08.06.2015;

Zrecenzowany/Reviewed/Рецензирована: 27.08.2015;

Opublikowany/Published/Опубликована: 30.09.2015;

\title{
Przestrzenna analiza zagrożeń na podstawie danych historycznych ${ }^{3}$
}

\author{
Spatial Analysis of Hazards Based on Historical Data
}

Пространственное размещение угроз на основе исторических данных

\begin{abstract}
ABSTRAKT
Cel: Opis metody przestrzennej analizy zagrożeń.

Wprowadzenie: W celu doskonalenia systemu ratownictwa potrzebna jest wiedza na temat występujących na danym obszarze zdarzeń wymagających działania służb ratowniczych. Powinna być ona rzetelnie udokumentowana, a metody wnioskowania wiarygodne. Wiedzę na ten temat czerpiemy zawsze z przeszłości. Może być ona zawarta w zbiorach danych lub w doświadczeniu ekspertów. Korzystanie z wiedzy i doświadczenia ekspertów jest niekiedy konieczne, jednakże zawsze obarczone subiektywizmem. Dane archiwalne natomiast są mniej subiektywne. Wymagają jednak stosowania odpowiednich narzędzi w procesie wydobywania z nich wiedzy i wnioskowania. Dokonując ukierunkowanej analizy statystycznej danych dotyczących pożarów i innych zdarzeń miejscowych, które miały miejsce na danym obszarze w określonym przedziale czasu, możemy wskazać na przestrzenne rozmieszczenie tych zdarzeń. Z przeprowadzonych badań wynika, że ewolucja zmian w rozkładzie gęstości zdarzeń krytycznych jest bardzo powolna. Pozwala to założyć, że rozkład gęstości zdarzeń krytycznych jest w kilkuletnich przedziałach czasowych stacjonarny. Prowadzenie zatem takich analiz może być bardzo przydatne do planowania: rozmieszczenia i potencjału jednostek ratowniczych, w kontekście narzuconych norm czasowych reakcji systemu ratowniczego na incydenty krytyczne.

Metodologia: Analiza i prognozowanie statystyczne.

Wnioski: Proces pojawiania się zdarzeń krytycznych na wybranym obszarze można opisać za pomocą stacjonarnego (w pewnym przedziale czasowym) procesu Poissona. Prognozy oparte na tym schemacie są w znacznym stopniu wiarygodne pod warunkiem, że oceny ryzyka wystąpienia zdarzeń krytycznych dokonamy agregując prognozy z obszarów podstawowych. Najmniejszym obszarem podstawowym dla takiej analizy może być kwadrat o pow. $1 \mathrm{~km}^{2}$ wyznaczony przez współrzędne topograficzne. Zliczamy liczbę zdarzeń krytycznych w poszczególnych kwadratach podstawowych na przestrzeni np. jednego roku. Rezultatem tego będzie mapa z historyczną gęstością zdarzeń krytycznych na wskazanym obszarze. Z przeprowadzonych badań wynika, że przyjmując wyznaczoną liczbę zdarzeń krytycznych w poszczególnych kwadratach, jako oczekiwaną liczbę zdarzeń krytycznych w rozkładzie Poissona, możemy z dużym stopniem wiarygodności prognozować liczbę zdarzeń krytycznych w roku następnym. Prognoza taka pomimo metodycznej prostoty jest prognozą w $90 \%$ wiarygodną. Starano się to wykazać w prezentowanym artykule.
\end{abstract}

Słowa kluczowe: analiza ryzyka, analiza statystyczna, prognozowanie statystyczne

Typ artykułu: oryginalny artykuł naukowy

\section{ABSTRACT}

Aim: To describe the process for the conduct of a spatial analysis of hazards. Introduction: Improvements to the rescue system require knowledge of incidents taking place in a given area, which need the intervention from rescue services. Such information ought to be scrupulously documented and inference methods should be plausible. Knowledge of issues is gained from past experience. This may be held on a database or derived from the experience of experts. Use of expert knowledge and experience is at times necessary, however, it is always weighed down with subjectivity. On the other hand, historical data

Uniwersytet Jana Kochanowskiego w Kielcach / The Jan Kochanowski University in Kielce;

2 Centrum Naukowo-Badawcze Ochrony Przeciwpożarowej - Państwowy Instytut Badawczy, Józefów / Scientific and Research Centre for Fire Protection - National Research Institute, Poland; jkielin@cnbop.pl;

3 Wkład merytoryczny w powstanie artykułu / Percentage contribution: J. Prońko - 60\%, J. Kielin - 20\%, B. Wojtasiak - 20\%; 
is less subjective. The use of historical data requires an application of appropriate tools during the process of knowledge extraction and formulation of conclusions. It is possible to reveal a spatial dispersion of incidents from a focused statistical analysis of historical data, about fires and other local incidents, which occurred in a given area within a specified time frame. Prior research reveals that evolutionary change in the distribution density of critical incidents is very slow. This allows for an assumption that the density distribution of critical incidents, in a time frame of several years, is static. Therefore, the production of such an analysis can be very useful for planning purposes, to deal with issues concerning the distribution and capability levels of fire stations in context of applied standards for speed of response, to address critical incidents.

Methodology: Analysis and statistical forecasting.

Conclusions: Emergence of critical incidents in selected areas may be described with the aid of a stationery (in a particularly compartmentalized time frame) Poisson distribution. Forecasts based on this approach have significant credibility, subject to the proviso that the risk evaluation of a critical incident event will be made by aggregating forecasts from initial base areas. The smallest base area for such an analysis may be a square with an area of $1 \mathrm{~km}^{2}$ identified by topographic co-ordinates. The number of critical incidents should be counted for each square over a period of say, one year. The result will reveal a map with a historical density of critical incidents for an identified target area. Research reveals that by accepting an identified number of critical incidents in individual squares, as an anticipated number of critical incidents in a Poisson distribution, it is possible to forecast the number of critical incidents in the following year with a high level of confidence. Such an estimate, despite the simplistic approach, is a forecast with $90 \%$ credibility, a point, which this article sought to demonstrate.

Keywords: risk analysis, statistical analysis, statistical forecasting

Type of article: original scientific article

\section{АННОТАЦИЯ}

Цель: Описание метода пространственного анализа угроз.

Введение: Для совершенствования системы спасения нужно обладать информацией относительно событий, которые происходят на данной территории, и которые требуют интервенции спасательных служб. Такая информация должна быть тщательно задокументирована, а методы подведения итогов - достоверны. Мы получаем её всегда из прошлого. Она может содержаться в базах данных или в опыте экспертов. Иногда использование знаний и опыта экспертов необходимо, но оно всегда связано с субъективизмом. Архивные данные менее субъективны. Однако, они требуют использования соответствующих инструментов в процессе извлечения информации и выводов. Проводя направленный статистический анализ данных, касающихся пожаров и других аварий, которые случились на данном участке в определённом промежутке времени, мы можем определить пространственное распределение этих событий. Из проведенных исследований следует, что эволюция изменений в распределении плотности критических явлений очень медленная. Это позволяет предположить, что плотность распределения критических явлений, появляющихся в период нескольких лет, стационарная. Поэтому, такие анализы могут быть очень полезны для планирования: распределения и потенциала спасательных единиц, в контексте обязательных стандартов времени реакции спасательной системы на критические инциденты.

Методология: Статистический анализ и прогнозирование.

Выводы: Процесс появления критических явлений на данном участке можно описать при помощи стационарного (в определенный период времени) процесса Пуассона. Прогнозы, основанные на этой схеме, в значительной степени достоверны при условии, что оценка риска появления критических явлений будет сделана путём объединения прогнозов с основных участков. Наименьшим основным участком для такого анализа может быть квадрат поверхностью 1 км², обозначенный топографическими координатами. Подсчитывается число критических событий в отдельных основных квадратах в течении, например, одного года. Результатом будет карта с исторической плотностью критических событий на определённом участке. Из проведенных исследований следует, что принимая данное число критических событий в отдельных квадратах в качестве ожидаемого числа событий в распределении Пуассона, можно с большой степенью уверенности прогнозировать число критических явлений в следующем году. Прогноз помимо методологической простоты является $90 \%$ достоверным методом, что и старались доказать авторы в данной статье.

Ключевые слова: анализ риска, статистический анализ, статистическое прогнозирование

Вид статьи: оригинальная научная статья

\section{Wstęp}

Podczas tworzenia bądź reorganizacji systemu ratowniczego zawsze stajemy w obliczu pytania: na ile ów system będzie skuteczny i efektywny? Skuteczność działania służb ratowniczych postrzegana jest najczęściej przez pryzmat szybkości reakcji oraz adekwatności wyposażenia i umiejętności ratowników. Jej wzrost możemy osiągać zarówno poprzez zwiększanie potencjału tych służb, jak i przez efektywniejsze ich wykorzystanie. We współczesnym świecie to ten drugi sposób jest wyznacznikiem postępu i rozwoju cywilizacyjnego. Tak naprawdę nie jest istotne, ile wydajemy pieniędzy, ale jaki efekt osiągamy. Jak wykazały japońskie przedsiębiorstwa, wdrażając filozofię Kaizen, doskonalenie jest procesem ciągłego poszukiwania oraz eliminacji marnotrawstwa sił i środków, a nie wtłaczania pieniędzy w skostniałe struktury. Podstawowym etapem procesu doskonalenia jest gruntowne zrozumienie sytuacji, dopasowanie się do niej, ujawnianie miejsc powstawania szeroko rozumianego marnotrawstwa i ich eliminacji. Pierwszym krokiem jest jednak pełne rozpoznanie sytuacji.

System ratownictwa konstruuje się w celu niesienia skutecznej pomocy ludziom doświadczającym różnego 
typu zdarzeń, które zagrażają ich życiu, zdrowiu i mieniu. Ma on skutecznie działać w przypadku zagrożeń miejscowych. Wielkość zdarzeń kwalifikujących się do tego miana nie jest precyzyjnie określona. Zależy ona od możliwości działania służb ratowniczych. W przypadku większych zdarzeń uruchamiany jest system zarządzania kryzysowego, który pozwala na mobilizację większej liczby sił i środków.

Doskonalenie systemu ratownictwa wymaga zatem wiedzy na temat występujących na danym obszarze zdarzeń wymagających działania służb ratowniczych. Powinna być ona rzetelnie udokumentowana, a metody wnioskowania wiarygodne. Wiedzę na ten temat czerpiemy zawsze $\mathrm{z}$ przeszłości. Może być ona zawarta w zbiorach danych lub w doświadczeniu ekspertów. Korzystanie z wiedzy i doświadczenia ekspertów jest niekiedy konieczne, jednakże zawsze obarczone subiektywizmem. Zarówno w sferze poznawczej, jak i prognostycznej. Dane archiwalne natomiast są mniej subiektywne, zwłaszcza jeżeli opieramy się na liczbach, a nie opiniach. Wymagają jednak stosowania odpowiednich narzędzi $\mathrm{w}$ procesie wydobywania $\mathrm{z}$ nich wiedzy i wnioskowania.

W każdej jednak sytuacji wnioski dotyczące oceny działania systemu ratownictwa płyną z przeszłości, a ewentualne zmiany i udoskonalenia sprawdzane będą w przyszłości. Rodzi się zatem kilka istotnych pytań:

- Jaki jest związek przyszłych zdarzeń z podobnymi z przeszłości?

- Jakich narzędzi użyć do tworzenia prognoz?

- Jak bardzo możemy tym prognozom wierzyć?

\section{Wprowadzenie metodyczne}

Prezentowana $\mathrm{w}$ niniejszym artykule metoda przestrzennej analizy zagrożeń miejscowych oparta została na informacjach o wydarzeniach z przeszłości zapisanych w rejestrach Państwowej Straży Pożarnej. Ich wstępna analiza wskazuje na sporadyczność występowania takich zdarzeń. Na analizowanym obszarze o powierzchni około $620 \mathrm{~km}^{2} \mathrm{w}$ rejestrach PSP zanotowano około $1300 \mathrm{zda}-$ rzeń w skali roku. Co daje około 3-4 zdarzeń dziennie, a w ujęciu przestrzennym - 1 wydarzenie na obszarze około $170 \mathrm{~km}^{2}$ dziennie, lub średnio 2 wydarzenia rocznie na $\mathrm{km}^{2}$. Wśród analizowanych zdarzeń można wyróżnić: pożary, wypadki i kolizje drogowe, usuwanie skutków działania sił natury, zabezpieczenie działania innych służb ratowniczych itp.

Nie ulega wątpliwości, że poszczególne incydenty krytyczne są wzajemnie niezależne i występują w sposób losowy. A zatem najlepszym modelem opisu ich występowania będzie model probabilistyczny. O ile do analizy przestrzennego rozkładu występowania zdarzeń krytycznych można wykorzystać empiryczne rozkłady zmiennych losowych, o tyle w sferze prognozowania niezbędne jest aproksymowanie ich rozkładami teoretycznymi. W tym celu dokonano wstępnej analizy danych empirycznych.

Wstępne badania przeprowadzono w oparciu o dane dotyczące obszaru jednego powiatu, którego obszar $620 \mathrm{~km}^{2}$ podzielono na obszary jednostkowe - kwadraty o powierzchni $1 \mathrm{~km}^{2}$, zgodnie z Państwowym Układem Współrzędnych Geodezyjnych 1992. Przestrzenny rozkład liczby pożarów w latach 2009-2011 na obszarze obejmującym 100 obszarów jednostkowych przedstawiono w tabeli 1 . Jak wynika $\mathrm{z}$ danych tam zawartych ulega on, $\mathrm{z}$ roku na rok, jedynie niewielkim zmianom, związanym z losowością zjawiska. Uogólniając, przestrzenny rozkład liczby pożarów w skali roku jest wystarczająco stabilny do stwierdzenia, że proces ich pojawiania się jest procesem stacjonarnym, przynajmniej na przestrzeni kilku lat.

Tabela 1. Przestrzenny rozkład liczby pożarów na obszarze $100 \mathrm{~km}^{2}$ w latach 2009-2011

Table 1. Spatial distribution of the number of fires in the area of $100 \mathrm{~km}^{2}$ during years 2009-2011

\begin{tabular}{|c|c|c|c|c|c|c|c|c|c|}
\hline \multicolumn{10}{|c|}{2009} \\
\hline & & & & & 12 & & & & \\
\hline & & 6 & 5 & & & & & & \\
\hline & 15 & 7 & 14 & 1 & & & & & \\
\hline & 8 & 7 & 12 & & & & & & \\
\hline & 11 & 4 & 10 & 14 & 11 & & & 2 & 2 \\
\hline 3 & 34 & 5 & 18 & 11 & 11 & 10 & & & \\
\hline 1 & 9 & 3 & 10 & 23 & 9 & & & & \\
\hline 6 & 2 & 14 & 7 & & & & & & \\
\hline 6 & 4 & 1 & 6 & 6 & & & 1 & 1 & 3 \\
\hline 10 & 3 & 5 & & 3 & & & & & \\
\hline
\end{tabular}

\begin{tabular}{|c|c|c|c|c|c|c|c|c|c|}
\hline \multicolumn{10}{|c|}{2010} \\
\hline & & & 5 & & 8 & & & & \\
\hline & & 3 & 2 & & & & & & \\
\hline & 6 & 8 & 14 & & 1 & & & & \\
\hline & 3 & 4 & 18 & & & & & & \\
\hline & 7 & 2 & 8 & 13 & 5 & & & 1 & 1 \\
\hline 2 & 34 & 6 & 13 & 18 & 23 & 15 & 2 & & \\
\hline 1 & 1 & 7 & 3 & 18 & 9 & & 2 & & 1 \\
\hline 1 & 4 & 9 & 9 & 1 & 1 & 1 & & & \\
\hline 5 & 3 & 4 & 1 & 4 & & & & & 1 \\
\hline 3 & 5 & 7 & & 2 & & & & & \\
\hline
\end{tabular}

\begin{tabular}{|c|c|c|c|c|c|c|c|c|c|}
\hline \multicolumn{10}{|c|}{2011} \\
\hline & & & 2 & & 15 & & & & \\
\hline & & 3 & 6 & & & & & & \\
\hline & 5 & 8 & 17 & & 3 & & & & \\
\hline & 18 & 9 & 16 & & & & 1 & & \\
\hline & 9 & 3 & 12 & 22 & 7 & & 1 & 4 & 2 \\
\hline 2 & 32 & 5 & 12 & 23 & 12 & 11 & & & \\
\hline 1 & 7 & 4 & 5 & 18 & 8 & & 4 & & 1 \\
\hline 3 & 4 & 18 & 6 & 1 & 3 & 4 & & & \\
\hline 2 & 2 & 7 & 4 & 11 & & 1 & 1 & & 4 \\
\hline 5 & 7 & 4 & 1 & 4 & & 3 & & 4 & \\
\hline
\end{tabular}

Źródło: Opracowanie własne na podstawie danych z bazy SWD-ST 2.5.

Source: Own elaboration on the basis of data from the database SWD-ST 2.5.

Podobnie, liczba obszarów jednostkowych o jednakowej liczbie pożarów dla całego rozpatrywanego obszaru w poszczególnych latach ulega niewielkim zmianom, co przedstawiono na rycinie 1 . Nie uwzględniono na niej obszarów jednostkowych, na których pożary nie wystąpiły. Ich liczba w poszczególnych latach wynosiła odpowiednio: rok 2008 - 472; rok 2009 - 483; rok 2010 - 484; rok 2011 - 469.

Liczba zdarzeń krytycznych na danym obszarze zależy od: 
- pokrycia terenu, a w szczególności infrastruktury i zabudowy terenu;

- gęstości zaludnienia;
- kultury zamieszkujących go ludzi, a w szczególności ich mentalności;

- przyzwyczajeń.

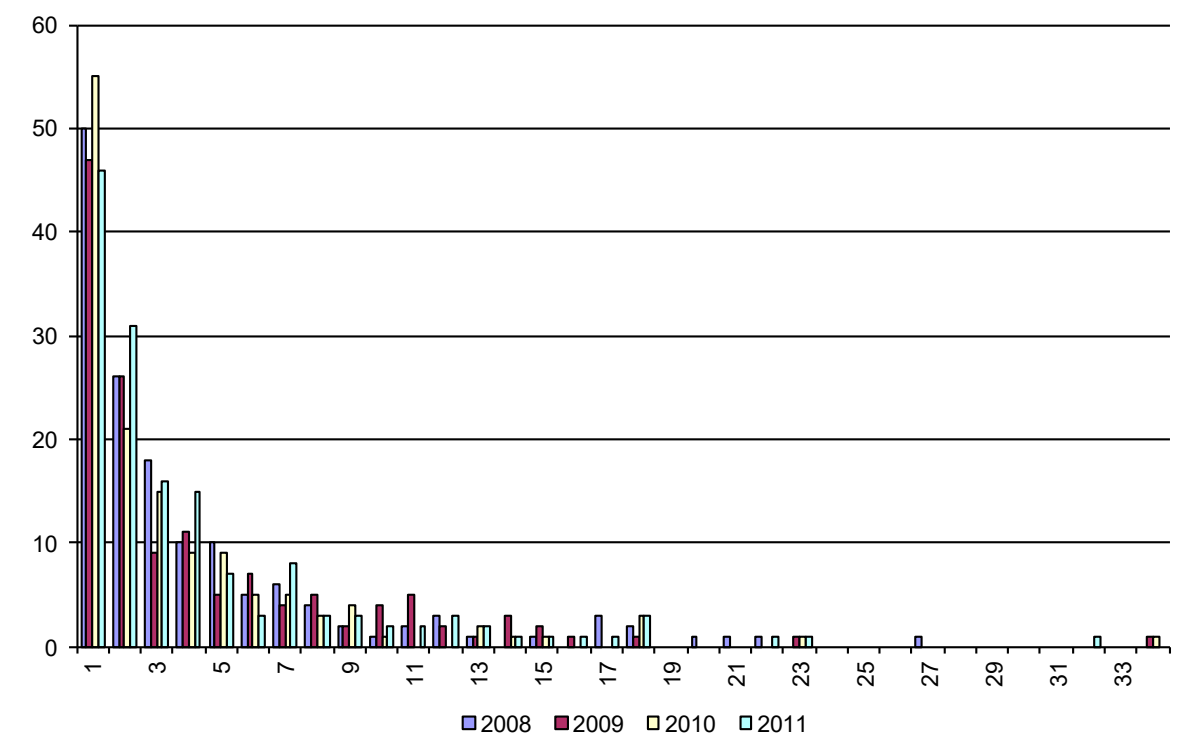

Ryc. 1. Histogramy empirycznych rozkładów pożarów na analizowanym terenie w latach 2008-2011

Fig. 1. Histograms of empirical distributions analyzed fires in the area in the years 2008-2011

Źródło: Opracowanie własne na podstawie danych z bazy SWD-ST 2.5.

Source: Personal elaboration on the basis of data from the database SWD-ST 2.5.

Wskazane elementy podlegają powolnej ewolucji, jednakże w dość znacznych (kilkuletnich) przedziałach czasowych można je uznać za stałe. Pozwala to przyjąć założenie o stacjonarności procesu pojawiania się kolejnych zdarzeń krytycznych, przynajmniej w przedziałach niezmienności wskazanych powyżej czynników. Założenie to potwierdzają również wyniki analiz przestrzennego rozkładu zdarzeń krytycznych, których najistotniejsze elementy przedstawiono powyżej.

Na podstawie powyższych analiz można założyć, że proces pojawiania się kolejnych zdarzeń krytycznych na danym obszarze można opisać stacjonarnym procesem Poissona. Typowa realizacja takiego procesu to funkcja skokowa o wartości skoku 1, której argumentem jest czas. Rozpoczyna się od wartości 0 , aby po pewnym czasie zmienić swą wartość na 1, a następnie 2, itd. Skok wartości o 1 dokonuje się w chwilach losowych. Jeżeli czas pojawiania się kolejnych skoków można opisać rozkładem wykładniczym o stałym parametrze $\lambda$, to proces ten nazywamy stacjonarnym.

Jak wynika z powyższego opisu, jest to typowy proces zliczający zdarzenia, wartość funkcji jest zawsze liczbą naturalną (początkowa wartość to 0), natomiast argumentem jest czas, który możemy opisywać w sposób ciągły lub dyskretny. W tym drugim przypadku musi być spełniony warunek, że przedziały czasu na jakie dzielimy okres obserwacji powinny być tak małe, aby prawdopodobieństwo pojawienia się dwóch zdarzeń w jednym przedziale czasowym było znikomo małe.

Dokładnie tak, jak opisano powyżej, pojawiają się zdarzenia krytyczne na badanym obszarze. Rozpoczynając obserwację od początku roku kalendarzowego, początkowa liczba zdarzeń krytycznych wynosi 0, po pewnym czasie pojawia się pierwsze zdarzenie, następnie drugie i kolejne. W rezultacie na koniec roku otrzymujemy sumę zdarzeń krytycznych za ubiegły rok. Czas pojawiania się kolejnych zdarzeń jest całkowicie losowy, a liczba zdarzeń w kolejnych latach jest wzajemnie niezależna. Aby wskazany opis procesu można było zastosować do prognozowania liczby zdarzeń w kolejnych latach, należy określić podstawowy parametr tego procesu - oczekiwaną liczbę zdarzeń lub oczekiwaną częstość ich pojawiania się. W przypadku procesu stacjonarnego zakładamy, że jest on taki sam dla kolejnych rozłącznych okresów obserwacji. Natomiast w przypadku procesu niestacjonarnego zakładamy, że parametr ten jest zmienny w czasie i znamy funkcję opisującą tę zmienność.

A zatem kolejnym krokiem powinno być określenie zależności między czasami pojawiania kolejnych zdarzeń krytycznych. Ze względu na ograniczenia objętościowe tekstu, analiza taka zostanie przedstawiona na przykładzie pojawiania się pożarów na wybranym obszarze obejmującym 16 km², czyli 16 obszarów jednostkowych.

Na wybranym obszarze w kolejnych latach było:

- 178 pożarów - 2008 rok;

- 175 pożarów - 2009 rok;

- 153 pożary - 2010 rok;

- 152 pożary - 2011 rok.

Podstawowe parametry rozkładów empirycznych czasu oczekiwania na kolejne zdarzenie przedstawiono w tabeli 2 . Okresy oczekiwania na kolejne zdarzenie liczono, jak w przypadku procesu Poissona - od północy 1 stycznia danego roku. 
Tabela 2. Podstawowe parametry rozkładów empirycznych czasu oczekiwania na kolejne zdarzenie w poszczególnych latach Table 2. Basic parameters of an empirical distribution of waiting time for the next event in subsequent years

\begin{tabular}{|c|c|c|c|c|}
\hline $\begin{array}{l}\text { Rok } \\
\text { Year }\end{array}$ & 2008 & 2009 & 2010 & 2011 \\
\hline $\begin{array}{l}\text { Sredni czas oczekiwania na zdarzenie (godz.) } \\
\text { The average time for an event (hrs.) }\end{array}$ & 49,13 & 49,28 & 56,85 & 56,92 \\
\hline $\begin{array}{l}\text { Najdłuższy czas oczekiwania na zdarzenie (godz.) } \\
\text { The longest waiting time for an event (hrs.) }\end{array}$ & 495,75 & 712,1 & 381,7 & 363,94 \\
\hline $\begin{array}{l}\text { Najkrótszy czas oczekiwania na zdarzenie (godz.) } \\
\text { The shortest waiting time for an event (hrs.) }\end{array}$ & 0,19 & 0,13 & 0,39 & 0,18 \\
\hline $\begin{array}{l}\text { Odwrotność średniego czasu oczekiwania }(\lambda) \text { (1/godz.) } \\
\text { The reciprocal of the average waiting time }(\lambda)(1 / \mathrm{hr} .)\end{array}$ & 0,0203 & 0,0203 & 0,0176 & 0,0176 \\
\hline
\end{tabular}

Źródło: Opracowanie własne na podstawie danych z bazy SWD-ST 2.5.

Source: Personal elaboration on the basis of data from the database SWD-ST 2.5.

Na rycinie 2. porównano gęstość prawdopodobieństwa empirycznych rozkładów czasu oczekiwania z gęstością prawdopodobieństwa rozkładów wykładniczych o średnim

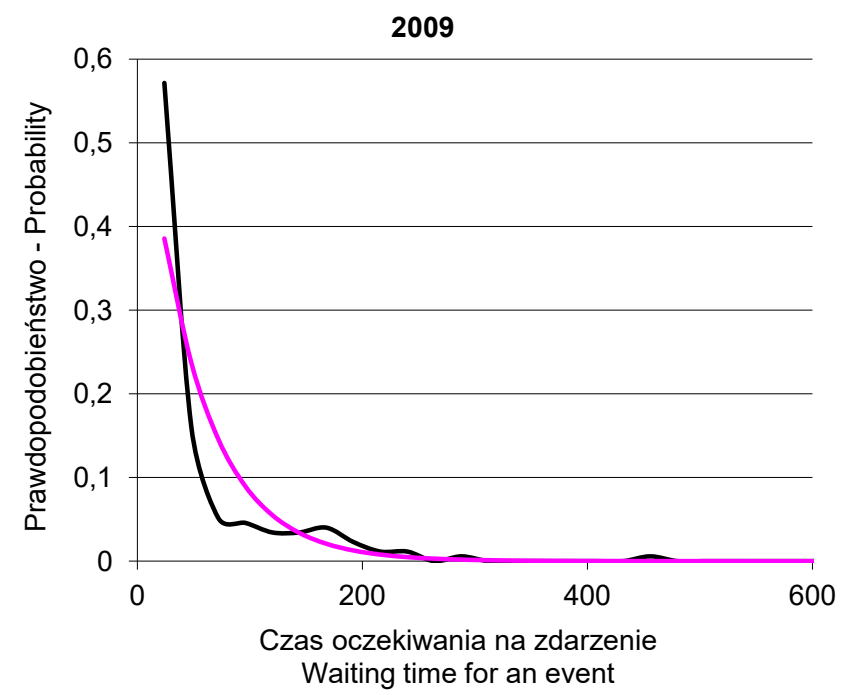

czasie oczekiwania wynikającym z tabeli 2. Ze względu na ograniczoną objętość artykułu przedstawiono tylko lata 2009 i 2010.

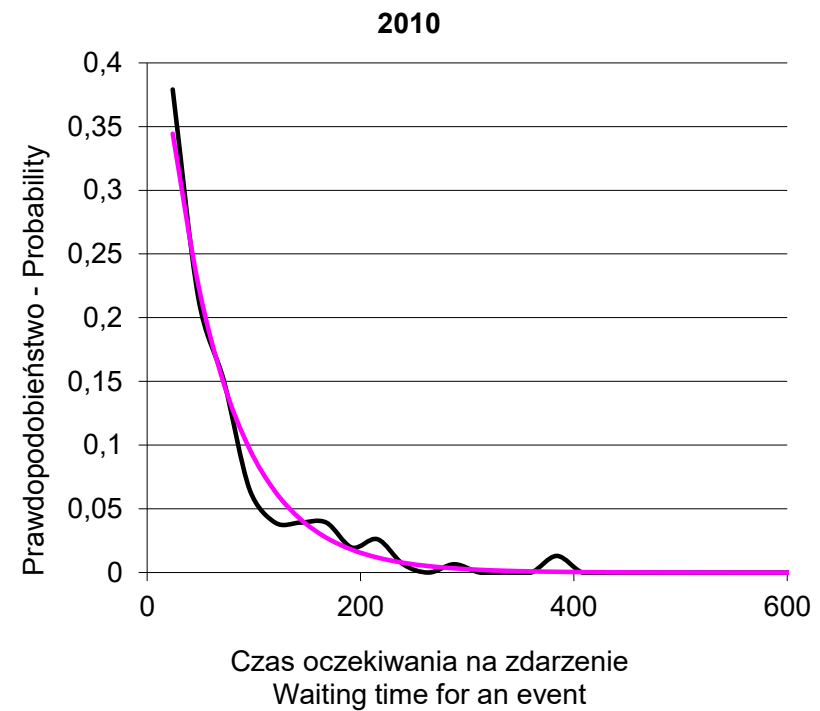

Ryc. 2. Porównania gęstości prawdopodobieństwa rozkładów empirycznych z teoretycznymi o tym samy współczynniku $\lambda$

Fig. 2. Comparison of probabilistic density for empirical and theoretical distributions using the same factor $\lambda$

Źródło: Opracowanie własne na podstawie danych z bazy SWD-ST 2.5.

Source: Own elaboration on the basis of data from the database SWD-ST 2.5.

Jak widać na ryc. 2., kształt funkcji gęstości prawdopodobieństwa rozkładu empirycznego i teoretycznego jest bardzo zbliżony. Dla weryfikacji powyższego wniosku oszacowano błąd średniokwadratowy dopasowania krzywej empirycznej do teoretycznej. Dla danych z roku 2009 błąd ten wynosił 0,0013, natomiast dla roku $2010-0,0004$. W pozostałych latach wynosił odpowiednio: 2008 r. - 0,0005; 2011 r. - 0,0008. Wielkość tego błędu zależy w znacznej mierze od ilości danych empirycznych poddanych analizie, jeżeli zatem podzielimy obszar na mniejsze podobszary to błąd średniokwadratowy dopasowania zwiększa się. I tak w przypadku obszarów podstawowych osiąga wartość na poziomie 0,02 . Na podstawie powyższych analiz można stwierdzić, że aproksymacja empirycznych rozkładów czasu oczekiwania na kolejne zdarzenie rozkładem wykładniczym o czasie oczekiwania na kolejne zdarzenie równym średniej czasów oczekiwania rozkładu empirycznego jest poprawna.

Zasadniczym problemem, w kontekście prognozowania przyszłych zdarzeń, jest pytanie: Czy empiryczny rozkład gęstości prawdopodobieństwa czasu oczekiwania na zdarzenie jest zbieżny z rozkładem teoretycznym opracowanym na podstawie danych z poprzedniego okresu obserwacji? Poszukując odpowiedzi na to pytanie, porównano kształt krzywej opisującej empiryczny rozkład gęstości prawdopodobieństwa $\mathrm{z}$ teoretycznym rozkładem wykładniczym o oczekiwanym czasie zajścia kolejnego zdarzenia równym średniej tego czasu z poprzedniego roku (zobacz ryc. 3) oraz wyznaczono błąd średniokwadratowy dopasowania tych funkcji. 
2010

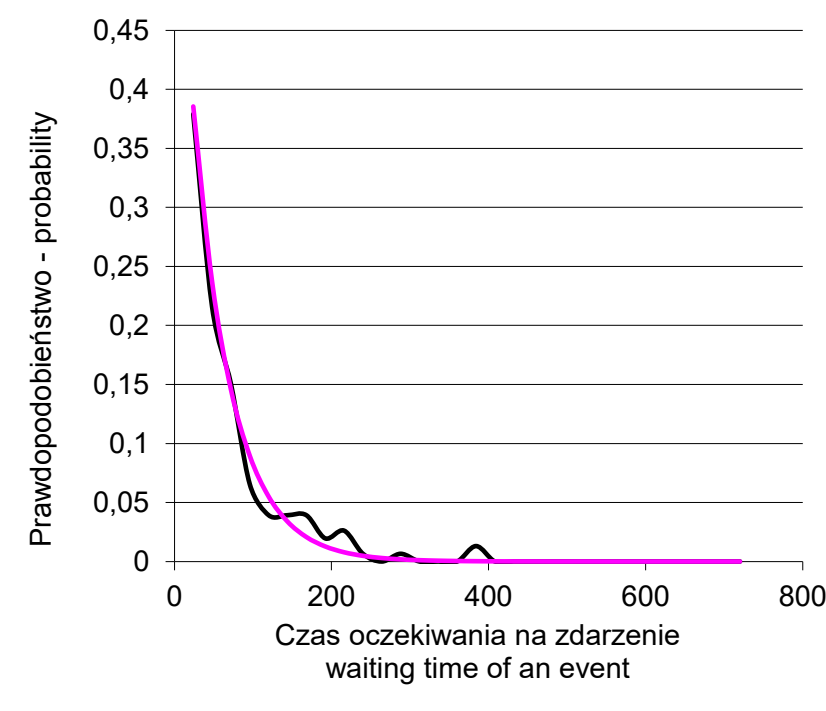

$-2010$

— Rozkład teoretyczny na podstawie danych z 2009 r. teoretical distribution on the basis of 2009 data

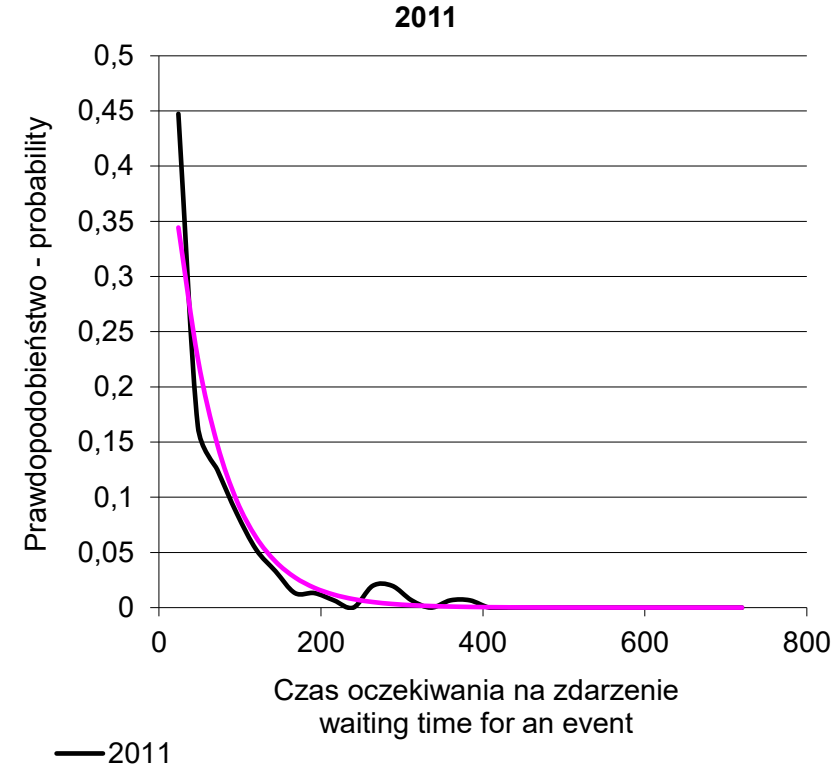

- Rozkład teoretyczny na podstawie danych z 2010 r. teoretical distribution on the basis of 2010 data

Ryc. 3. Porównania gęstości prawdopodobieństwa rozkładów empirycznych z teoretycznymi o współczynniku $\lambda$ $\mathrm{z}$ roku poprzedniego

Fig. 3. Comparisons probability density distributions of empirical and theoretical coefficient of $\lambda$ from the previous year Źródło: Opracowanie własne na podstawie danych z bazy SWD-ST 2.5.

Source: Own elaboration on the basis of data from the database SWD-ST 2.5.

Podobnie jak w poprzednim przypadku kształty tych funkcji są bardzo zbliżone. Podobnie błąd średniokwadratowy ich dopasowania wynosi odpowiednio: rok 2009 - 0,0013; rok 2010 - 0,0003; rok $2011-0,0008$.

$\mathrm{W}$ dotychczasowych analizach średni czas oczekiwania na zdarzenie szacowano na podstawie faktycznych czasów oczekiwania. W praktyce może to być dość uciążliwe. Analizując dane historyczne, wykazano, że czas oczekiwania na kolejne zdarzenie krytyczne bardzo dobrze opisuje rozkład wykładniczy (zob. ryc. 2), którego dystrybuantę możemy opisać wzorem:

$$
p(T, \lambda)=1-e^{-\lambda T}
$$

gdzie: $p(T, \lambda)$ - prawdopodobieństwo, że kolejne zdarzenie zaistnieje w czasie T od zdarzenia poprzedniego (początku obserwacji); $\lambda$ - częstość zdarzeń - liczba zdarzeń w jednostce czasu.
Liczbę zdarzeń w jednostce czasu $(\lambda)$, w dotychczasowych rozważaniach, określano jako odwrotność średniej z czasów oczekiwania na kolejne zdarzenia. Załóżmy, że znamy jedynie liczbę zdarzeń w roku $(k)$. Wówczas częstość zdarzeń $(\lambda)$ w jednostce czasu (godz.) możemy oszacować $\mathrm{z}$ następującej zależności:

$$
\lambda=\frac{k}{8760}
$$

gdzie: 8760 - liczba godzin w roku kalendarzowym (nieprzestępnym)

Z analizy danych empirycznych (zob. tabela 3) wynika, że różnice między tymi dwoma metodami oszacowania parametru $(\lambda)$ są znikome. Można zatem, zamiast uciążliwej metody szacowania czasu oczekiwania na kolejne zdarzenie $\mathrm{z}$ analizy danych empirycznych (metoda I), skorzystać $\mathrm{z}$ metody uproszczonej - podzielić oczekiwaną liczbę zdarzeń w danym przedziale czasowym (roku) przez liczbę jednostek czasu objętych tym przedziałem $(8760$ h) (metoda II).

Tabela 3. Częstość zdarzeń wyznaczona dwoma metodami: metoda I - średnia z danych empirycznych; metoda II - z ilości zdarzeń w roku

Table 3. Frequency of events determined by two methods: Method I - average empirical data; Method II - the number of events per year

\begin{tabular}{|l|c|c|c|c|c|}
\hline \multicolumn{2}{|c|}{} & \multicolumn{4}{|c|}{ Rok / Year } \\
\cline { 3 - 5 } & $\mathbf{2 0 0 8}$ & $\mathbf{2 0 0 9}$ & $\mathbf{2 0 1 0}$ & $\mathbf{2 0 1 1}$ \\
\hline \multirow{3}{*}{$\begin{array}{l}\text { metoda I } \\
\text { method I }\end{array}$} & $\begin{array}{c}\text { średni czas oczekiwania na zdarzenie (godz.) } \\
\text { the average waiting time for an event (hrs.) }\end{array}$ & 49,13517 & 49,2856 & 56,85379 & 56,92954 \\
\cline { 2 - 5 } & $\begin{array}{c}\text { częstość zdarzeń } \lambda \text { [1/godz.] } \\
\text { eventrate } \lambda[1 / \text { hr.] }\end{array}$ & 0,020352 & 0,02029 & 0,017589 & 0,017566 \\
\hline
\end{tabular}




\begin{tabular}{|c|c|c|c|c|c|}
\hline \multicolumn{2}{|c|}{} & \multicolumn{4}{|c|}{ Rok / Year } \\
\cline { 2 - 5 } & $\begin{array}{c}\text { liczba zdarzeń w roku } \\
\text { the number of events per year }\end{array}$ & $\mathbf{2 0 0 8}$ & $\mathbf{2 0 0 9}$ & $\mathbf{2 0 1 0}$ & $\mathbf{2 0 1 1}$ \\
\hline \multirow{3}{*}{$\begin{array}{l}\text { metoda II } \\
\text { method II }\end{array}$} & $\begin{array}{c}\text { średni czas oczekiwania (8760/k) } \\
\text { the average waiting time }(8760 / \mathrm{f}\end{array}$ & 49,21348 & 50,34483 & 57,63158 & 58,01325 \\
\cline { 2 - 6 } & $\begin{array}{c}\text { częstość zdarzeń } \lambda \text { [1/godz.] } \\
\text { event rate } \lambda[1 / \text { hr.] }\end{array}$ & 0,02032 & 0,019863 & 0,017352 & 0,017237 \\
\hline
\end{tabular}

Źródło: Opracowanie własne na podstawie danych z bazy SWD-ST 2.5.

Source: Own elaboration on the basis of data from the database SWD-ST 2.5.

Na podstawie wynikow badań, ktore w skróconej formie zaprezentowano w tej części artykułu, możemy stwierdzić, że:

- proces pojawiania się kolejnych zdarzeń krytycznych w skali roku można opisać za pomocą stacjonarnego procesu Poissona;

- proces pojawiania się zdarzeń krytycznych jest procesem stacjonarnym na przestrzeni kilku lat;

- do prognozowania liczby zdarzeń w kolejnym roku można przyjąć, jako wartość oczekiwaną, liczbę zdarzeń z roku poprzedniego;

- można również, jako wartość oczekiwaną, przyjąć średnią z kilku ostatnich lat (w przypadku małej liczby zdarzeń danego rodzaju), jednakże sięganie w przeszłość ma swoje ograniczenia związane ze: zmianami w pokryciu terenu, jego zabudowie, gęstości zaludnienia oraz zmian w kulturze społecznej; wskazane uwarunkowania ograniczają wiarygodny przedział czasowy do trzech lat poprzedzających.

Reasumując, można stwierdzić, że proces pojawiania się kolejnych zdarzeń krytycznych na wskazanym obszarze $\mathrm{w}$ danym roku jest stacjonarnym procesem Poissona o wartości oczekiwanej równej liczbie zdarzeń z roku ubiegłego lub średniej z maksymalnie trzech lat poprzedzających.

\section{Prognozowanie}

Podstawowym parametrem rozkładu Poissona jest oczekiwana liczba zdarzeń $(\lambda)$ w danym przedziale czasowym (T) na określonym obszarze (S). Znając ten parametr i przyjmując jego stałość $\mathrm{w}$ rozpatrywanym okresie czasu (proces stacjonarny), możemy wyznaczyć prawdopodobieństwo pojawienia się k zdarzeń na tym obszarze (S) w zadanym czasie (T) ze wzoru (funkcja gęstości prawdopodobieństwa):

$$
P(k ; \lambda)=\frac{\lambda^{k}}{k !} \cdot e^{-\lambda}
$$

Natomiast prawdopodobieństwo pojawienia się co najwyżej k zdarzeń na tym obszarze (S) w określonym przedziale czasu (T) wyznaczamy ze wzoru (dystrybuanta rozkładu):

$$
P\{i \leq k ; \lambda\}=e^{-\lambda} \cdot \sum_{i=1}^{k} \frac{\lambda^{i}}{i !}
$$

Załóżmy, że chcemy wyznaczyć prawdopodobieństwo pojawienia się $k$ zdarzeń na danym obszarze (S), ale w przedziale czasowym $n$ razy dłuższym. Uwzględniając stacjonarność procesu, należy stwierdzić, że oczekiwana liczba zdarzeń $(\lambda)$ w każdym z $n$ przedziałów czasowych będzie taka sama, a zatem oczekiwana liczba zdarzeń w przedziale $n^{\star} T$ będzie równa $n^{\star} \lambda$. A zatem prawdopodobieństwo pojawienia się $\mathrm{k}$ zdarzeń $\mathrm{w}$ przedziale $\mathrm{n}$ razy dłuższym od T będzie wynosić:

$$
p(k ; n \lambda)=\frac{(n \lambda)^{k}}{k !}
$$

Przez analogię przedział czasowym możemy podzielić na $n$ przedziałów o jednakowej długości, wówczas:

$$
\lambda^{\prime}=\frac{\lambda}{n} \rightarrow p\left(k ; \frac{\lambda}{n}\right)=\frac{\left(\frac{\lambda}{n}\right)^{k}}{k !}
$$

Podobnie jest w przypadku łączenia obszarów o znanych wartościach oczekiwanych liczb zdarzeń. Natomiast podział obszaru na mniejsze elementy jest możliwy jedynie przy założeniu, że wartość oczekiwana liczby zdarzeń jest taka sama dla każdego z podobszarów.

Załóżmy, że powiat składa się z 5 gmin. W danym roku zanotowano $\mathrm{w}$ poszczególnych gminach odpowiednio: $\lambda_{1}, \lambda_{2}, \lambda_{3}, \lambda_{4}, \lambda_{5}$ zdarzeń. Wówczas liczba zdarzeń zanotowanych $\mathrm{w}$ całym powiecie będzie równa sumie zdarzeń z poszczególnych gmin. Przyjmując zanotowaną liczbę zdarzeń, jako ich wartość oczekiwaną w roku przyszłym (zgodnie z wnioskami z poprzedniego rozdziału) możemy stwierdzić, że oczekiwana liczba zdarzeń w roku przyszłym dla całego powiatu będzie sumą oczekiwanej liczby zdarzeń w poszczególnych gminach.

Znając oczekiwaną liczbę zdarzeń $(\lambda)$ na danym obszarze (S) w określonym przedziale czasu (T), można wyznaczyć prawdopodobieństwo pojawienia się kolejnego zdarzenia w określonej odległości czasowej od zdarzenia poprzedniego.

Załóżmy, że w chwili t ${ }_{0}$ zaszło zdarzenie, chcemy wyznaczyć prawdopodobieństwo pojawienia się kolejnego zdarzenia $\mathrm{w}_{\text {chwili }} \mathrm{t}_{1}$. Przyjmijmy również, że oczekiwana liczba zdarzeń w określonym przedziale czasowym (T) wynosi $\lambda$. Wówczas liczba zdarzeń w jednostce czasu (min) wyniesie:

$$
\mu=\frac{\lambda}{T}\left[\frac{1}{\min }\right]
$$

A zakładana odległość czasowa między zdarzeniami wyniesie:

$$
t=t_{1}-t_{0}
$$

Załóżmy ponadto, że czas mierzymy w sposób dyskretny z dokładnością do jednostki czasu (np. 1 min). Z założenia tego wynika, że jeżeli w pierwszej minucie zaszło zdarzenie, a następne zaistniało między początkiem i końcem trzeciej 
minuty, to według naszej miary zaszło ono w trzeciej minucie, a odległość czasowa między pierwszym i drugim zdarzeniem wyniesie według naszej miary dwie minuty. Prawdopodobieństwo, że do czasu $t_{1}$ nie zajdzie zdarzenie możemy wyznaczyć ze wzoru:

$$
p\left(k=0 \text { dla } t \leq t_{1} ; \mu\right)=e^{-\mu t_{1}}
$$

Natomiast prawdopodobieństwo, iż pierwsze zdarzenie pojawi się dopiero po czasie $t_{1}$ możemy wyznaczyć ze wzoru:

$$
P\left\{k>0 \text { dla } t>t_{1} ; \mu\right\}=1-e^{-\mu t_{1}}
$$

Powyższe równanie opisuje dystrybuantę rozkładu wykładniczego, natomiast gęstość prawdopodobieństwa opisana jest wzorem:

$$
P\left\{k=1 \text { dla } t \leq t_{1} ; \mu\right\}=\mu e^{-\mu t_{1}}
$$

Z powyższych wzorów wynika, że rozkład Poissona jest ściśle związany z rozkładem wykładniczym, który opisuje rozkład losowy odstępów czasowych między kolejnymi zdarzeniami.

Rozkład Poissona poza ścisłym związkiem z rozkładem wykładniczym wykazuje również pewne własności predykcyjne, przydatne dla oceny ryzyka w najbliższej przyszłości. Jedną $\mathrm{z}$ tych własności jest brak pamięci w rozkładzie wykładniczym, czyli przyszłe realizacje tego rozkładu nie zależą od przeszłości, a jedynie od jego parametrów. Własność tę zachowuje również proces Poissona. Liczba zdarzeń w danym przedziale czasowym nie zależy od tego co zdarzyło się w poprzednich okresach czasu, a jedynie od parametrów tego procesu, czyli oczekiwanej liczby zdarzeń. Kolejną własność zobrazowano na rycinach 4 i 5 przedstawiających gęstość prawdopodobieństwa i dystrybuantę dla wybranych wartości $k$ (oczekiwanej liczby zdarzeń).

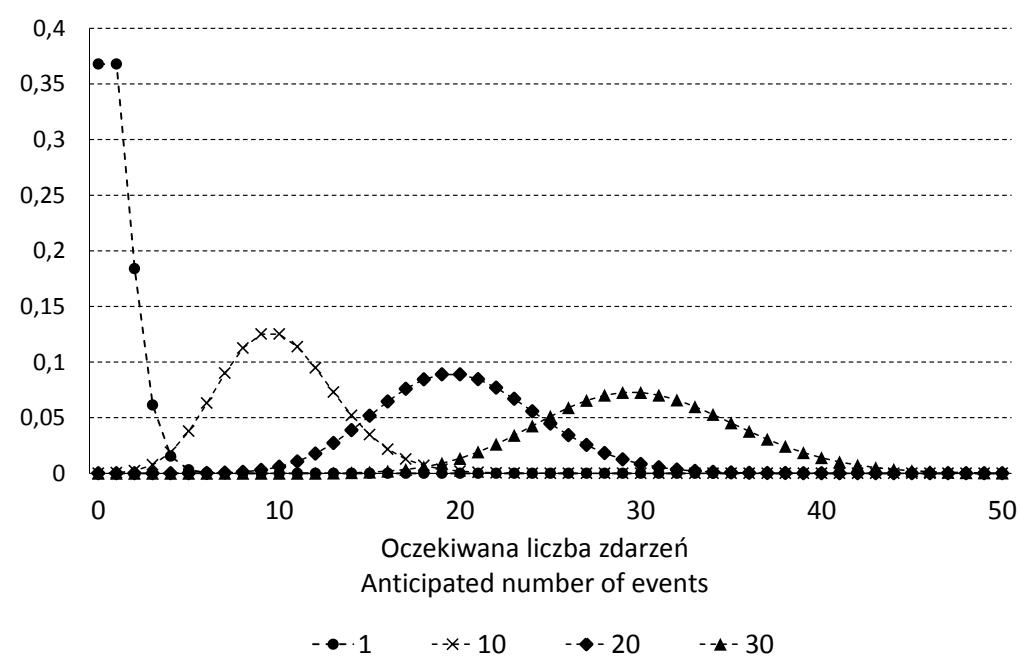

Ryc. 4. Rozkład prawdopodobieństwa rozkładu Poissona dla różnych wartości oczekiwanej liczby zdarzeń Fig. 4. Probability distribution function of Poisson distribution for different values of anticipated number of events Źródło: Opracowanie własne.

Source: Own elaboration.

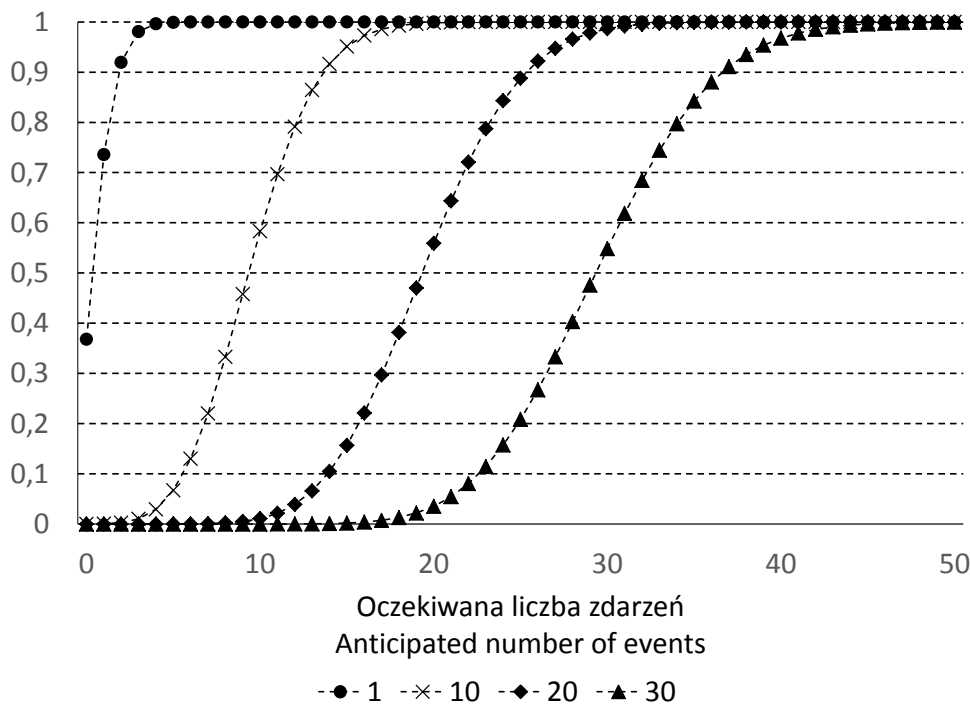

Ryc. 5. Dystrybuanta rozkładu Poissona dla różnych wartości oczekiwanej liczby zdarzeń

Fig 5. Probability distribution function of Poisson distribution for different values of the anticipated number of events

Źródło: Opracowanie własne.

Source: Own elaboration. 
Na przedstawionych rycinach wyraźnie widać, że zaobserwowana w danym przedziale czasowym liczba zdarzeń mieści się w pewnym zakresie zależnym od oczekiwanej liczby zdarzeń. Wielkość tego zakresu można wyznaczyć przy założonym poziomie ufności $(1-\alpha)$ dla otrzymanego wyniku. Ujmując problem nieco inaczej, możemy wyznaczyć zakres przyszłych realizacji zmiennej losowej, jaką jest liczba zdarzeń w zadanym przedziale czasowym, z maksymalnym dopuszczalnym błędem $a$. Zakres ten nazywamy w statystyce przedziałem ufności dla oczekiwanej liczby zdarzeń. Możemy to zapisać w następującej postaci matematycznej:

$$
P\{A \leq l \leq B\}=1-\alpha
$$

Zakładając poziom istotności $\alpha=0,1$, ucinamy zakres dystrybuanty rozkładu na poziomie $\mathrm{p}=0,05$ oraz $\mathrm{p}=0,95$.
Wyznaczone w ten sposób wartości A i B wskazują zakres przyszłych realizacji liczby zdarzeń w zadanym przedziale czasowym na standardowym obszarze na poziomie ufności $(1-\alpha)=0,9$, ponieważ:

$$
P\{A \leq l \leq B\}=P\{l \leq B\}-P\{l \leq A\}=0,95-0,05=0,9
$$

Dolną granicę A przedziału ufności możemy wyznaczyć ze wzoru:

$$
p\{l \leq A\}=0,05 \rightarrow \sum_{l=0}^{A} \frac{\lambda^{l}}{l !} e^{-\lambda}=0,05
$$

Górną granicę B przedziału ufności możemy wyznaczyć ze wzoru:

$$
p\{l \leq B\}=0,95 \rightarrow \sum_{l=0}^{B} \frac{\lambda^{l}}{l !} e^{-\lambda}=0,95
$$

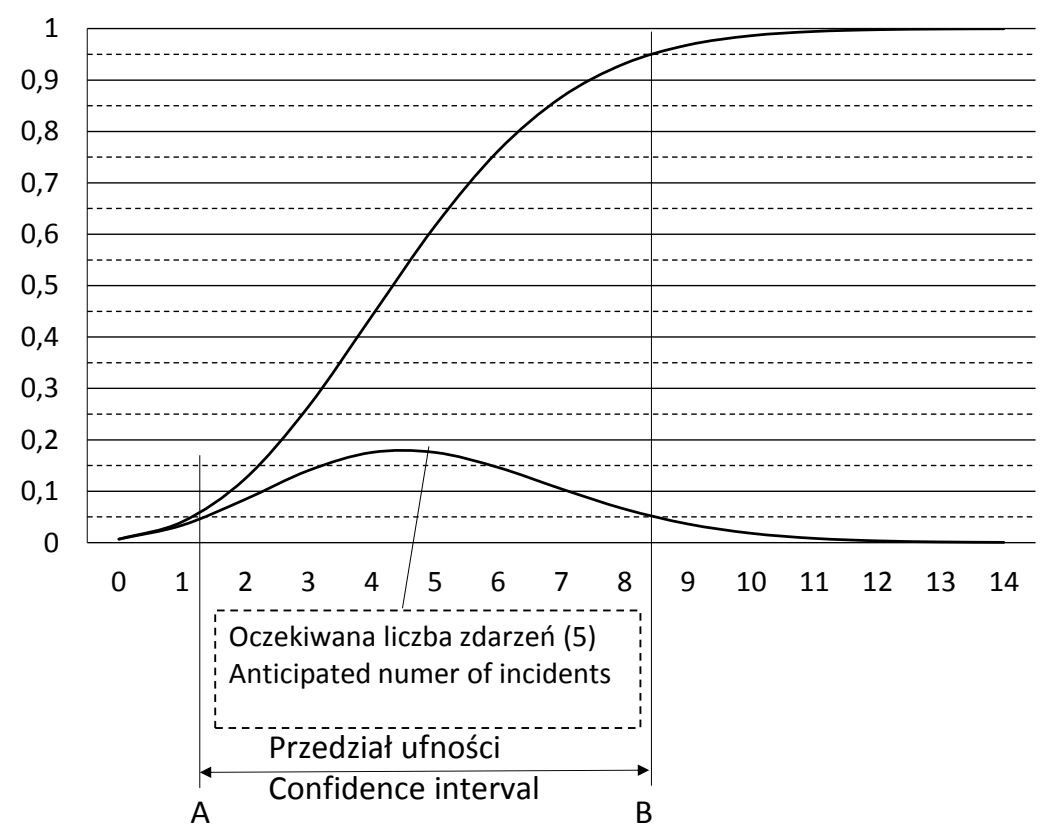

Ryc. 6. Graficzna prezentacja prognozowania liczby zdarzeń z wykorzystaniem rozkładu Poissona przy oczekiwanej ich liczbie 5 oraz poziomie ufności 0,9

Fig. 6. Graphic presentation of predicting the number of events using the Poisson distribution with an anticipated number of 5 and a confidence level of 0.9

Źródło: Opracowanie własne.

Source: Own elaboration.

Określanie przedziału ufności przy zadanym poziomie ufności przedstawiono na rycinie 8 , z której można odczytać, że dla oczekiwanej liczby 5 zdarzeń przedział ten wynosi od 2 do 8 na poziomie ufności 0,9. Oznacza to, że w następnym okresie czasowym na tym obszarze należy oczekiwać od 2 do 8 incydentów. Najbardziej prawdopodobne są 4 lub 5 zdarzeń.

W tabeli 4 zestawiono prognozowane liczby zdarzeń dla różnych wartości oczekiwanej ich liczby przy poziomie ufności 0,9.

Tabela 4. Zestawienie przewidywanej liczby zdarzeń dla różnych wartości oczekiwanej ich liczby przy poziomie ufności 0,9 Table 4. Statement of the expected number of events for different values of anticipated numbers at a confidence level of 0.9

\begin{tabular}{|c|c|c|}
\hline \multirow{2}{*}{$\begin{array}{c}\text { Oczekiwana liczba zdarzeń / Anticipated } \\
\text { number of incidents }\end{array}$} & \multicolumn{2}{|c|}{$\begin{array}{c}\text { Przewidywana liczba zdarzeń / } \\
\text { Expected number of incidents }\end{array}$} \\
\cline { 2 - 3 } & Minimalna / Minimum & Maksymalna / Maximum \\
\hline 1 & 0 & 2 \\
\hline 2 & 1 & 5 \\
\hline 3 & & 5 \\
\hline
\end{tabular}


DOI:10.12845/bitp.39.3.2015.7

\begin{tabular}{|c|c|c|}
\hline \multirow{2}{*}{$\begin{array}{c}\text { Oczekiwana liczba zdarzeń / Anticipated } \\
\text { number of incidents }\end{array}$} & \multicolumn{2}{|c|}{$\begin{array}{c}\text { Przewidywana liczba zdarzeń / } \\
\text { Expected number of incidents }\end{array}$} \\
\cline { 2 - 3 } & Minimalna / Minimum & Maksymalna / Maximum \\
\hline 4 & 2 & 8 \\
\hline 5 & 2 & 9 \\
\hline 6 & 3 & 11 \\
\hline 7 & 4 & 12 \\
\hline 8 & 4 & 13 \\
\hline 9 & 5 & 15 \\
\hline 10 & & \\
\hline
\end{tabular}

Źródło: Opracowanie własne.

Source: Own elaboration.

Reasumując, najważniejsze dla potrzeb niniejszego artykułu własności procesu Poissona to:

- brak pamięci - przyszłe realizacje zależą jedynie od parametrów procesu, nie zaś od jego historii;

- występuje ścisły związek między procesem Poissona i rozkładem wykładniczym;

- możliwość łączenia przedziałów czasowych i obszarów przestrzennych;

- możliwość dzielenia przedziałów czasowych oraz ograniczona w zakresie obszarów przestrzennych, ze względu na ich niejednorodność;

- ograniczony zakres przyszłych realizacji procesu w zadanym przedziale czasowym $(\mathrm{T})$ i obszarze (S) zależnym od parametrów procesu i przyjętego poziomu ufności dla prognozy.

\section{Algorytm przestrzennej analizy ryzyka incydentów krytycznych}

Przestrzenna analiza zdarzeń krytycznych pozwala wyspecyfikować obszary o szczególnym natężeniu zjawisk danego typu. Może być ona pomocna w:

- opracowaniu programów profilaktycznych oraz działań w zakresie zapobiegania tego typu zjawiskom na danym obszarze;

- w procesie kształtowania potencjału i rozmieszczenia służb ratowniczych w danym rejonie.

Należy jednak pamiętać o ograniczeniach tej metody wynikających ze specyfiki zjawisk przypadkowych - wiarygodne zobrazowanie zjawiska uzyskujemy jedynie przy odpowiedniej liczbie zdarzeń. Ich liczbę można wyznaczyć na podstawie przedziału ufności dla szacowanego parametru - oczekiwanej liczby zdarzeń.

Przedział ufności na poziomie 0,95 dla oczekiwanej liczby zdarzeń w rozkładzie Poissona można z dobrym przybliżeniem oszacować, wykorzystując następujące wzory [1]:

$$
\begin{aligned}
& \lambda_{d}=\frac{n}{l} \cdot\left(1-\frac{1,96}{\sqrt{n-1}}\right) \\
& \lambda_{g}=\frac{n}{l} \cdot\left(1+\frac{1,96}{\sqrt{n-1}}\right)
\end{aligned}
$$

gdzie: $n$ - liczba próbkowanych punktów lub zdarzeń; $l$-długość linii próbek (lub przedział czasowy);
Stosując powyższe zależności, do oceny oszacowania oczekiwanej liczby zdarzeń należy przyjąć:

- $\mathrm{n}$ - liczba zdarzeń na terenie powiatu w czasie 1 roku;

- 1 - liczba obszarów podstawowych obejmujących dany powiat.

Obszar podstawowy to fragment obszaru, który przyjmiemy jako obszar jednostkowy. Może nim być np.: gmina lub teren wyznaczony przez linie siatki topograficznej np.: w Państwowym Układzie Współrzędnych Geodezyjnych 1992 lub wielokrotność tego obszaru obejmującego na przykład $4 \mathrm{~km}^{2}$. Wybór zależy od celu jakiemu ma służyć przygotowywana analiza.

Średnia liczba zdarzeń przypadających na jeden obszar podstawowy $(\lambda)$ wynosi: $\frac{n}{l}$. Górną i dolną granicę przedziału ufności dla otrzymanego wyniku określają powyższe wzory. Granice te są symetryczne do wartości oczekiwanej $(\lambda)$. Stąd odległość granicy górnej od wartości oczekiwanej wynosi:

$$
\lambda_{g}-\lambda=\lambda \cdot \frac{1,96}{\sqrt{n-1}}
$$

Dokonując przekształceń powyższych wzorów, otrzymamy:

$$
n=1+\left(\frac{1,96}{\delta \lambda}\right)^{2} \approx\left(\frac{1,96}{\delta \lambda}\right)^{2}
$$

Gdzie: $\delta \lambda=\frac{\lambda_{g}-\lambda}{\lambda}-$ względny błąd oszacowania wartości oczekiwanej $(\lambda)$ przy założonym powyżej poziomie ufności 0,95 dla otrzymanego wyniku.

Uwzględniając powyższe: oszacowanie oczekiwanej liczby zdarzeń zawierało się będzie w zakresie $\lambda=\bar{\lambda} \pm 0,1 \cdot \bar{\lambda}$ (przy poziomie ufności 0,95 ), jeżeli liczba zdarzeń uwzględniana przy jego wyznaczaniu będzie wynosić co najmniej 385. Wyznaczona liczba zdarzeń nie zależy od liczby obszarów podstawowych, a jedynie od liczby zdarzeń dla całego rozpatrywanego obszaru. Wskazana metoda określania niezbędnej liczby zdarzeń dla osiągnięcia wymaganego stopnia dokładności zakłada, iż rozkład wartości oczekiwanej w poszczególnych obszarach podstawowych (np.: $\left.1 \mathrm{~km}^{2}\right)$ jest $\mathrm{w}$ miarę równomierny na całym rozpatrywanym obszarze. Oznacza to, iż w poszczególnych obszarach podstawowych prawdopodobieństwo zaistnienia zdarzenia jest podobne (nie 
znaczy takie same). Dlatego też prognozy będą mniej dokładne dla obszarów podstawowych, na których zarejestrowana liczba zdarzeń znacznie odbiega od przeciętnej liczby zdarzeń.

Uwzględniając powyższe, można określić algorytm prowadzenia analizy przestrzennego rozkładu zdarzeń krytycznych:

1. Wybieramy rodzaj analizowanych zdarzeń oraz określamy ich liczbę na rozpatrywanym obszarze, np.: na terenie jednego powiatu, jeżeli liczba tych zdarzeń w skali roku jest mniejsza od minimalnej liczby zdarzeń dla założonego przedziału ufności oszacowania parametru $(\lambda)$, to $\mathrm{w}$ analizach uwzględniamy zdarzenia tego samego typu z lat poprzednich (zwiększa to liczbę próbek i zdarzeń).

2. Dzielimy rozpatrywany obszar na obszary podstawowe, w zależności od potrzeb prowadzonej analizy, należy jednak pamiętać, że przyszła agregacja obszarowa danych jest możliwa, natomiast nie jest możliwa operacja odwrotna. Stąd też należy wybierać jak najmniejsze obszary podstawowe, np.: wyznaczone przez linie siatki topograficznej.

3. Zliczamy liczbę zdarzeń w poszczególnych obszarach podstawowych w skali jednego roku lub liczymy średnią, jeżeli wykorzystujemy dane z kilku lat.

4. Na podstawie wyznaczonej oczekiwanej liczby zdarzeń $(\lambda)$ dla każdego obszaru podstawowego dokonujemy oszacowania przedziału zdarzeń z przyjętym arbitralnie poziomem ufności np.: 0,95, wykorzystując własności rozkładu Poissona wskazane na rycinie 4, 5 oraz w tabeli 4.

5. Otrzymane prognozy można pogrupować, ponieważ ich wartość jest bardzo podobna dla kilku wartości parametru $\lambda$, np. dla $\lambda=9,10$ oraz 11, przedział przewidywanej liczby zdarzeń zawiera się między 5 a 15 przy poziomie ufności 0,95 . Przy takim grupowaniu dla $\lambda=9$ osiągnięcie górnej granicy liczby zdarzeń jest mniej prawdopodobne niż dolnej, jednakże różnice są minimalne. Agregując zmniejszamy natomiast liczby różnych kategorii obszarów podstawowych ze względu na prognozowaną liczbę zdarzeń, co pozwala na bardziej czytelne zaprezentowanie wyników analizy, na przykład z zastosowaniem kolorów.
6. Prezentujemy otrzymane wyniki na mapie poprzez podkolorowanie obszarów podstawowych (patrz punkt poprzedni) lub oznaczenie ich w inny sposób.

\section{Przykłady}

Poniżej przedstawione zostały przykłady zastosowania proponowanej metody dla trzech powiatów $\mathrm{z}$ różnych województw. Prezentacja ta nie tylko pozwala zobrazować schemat postępowania, ale również ocenić wiarygodność proponowanej metody. Ze względów formalnych nazwy tych powiatów oraz dane pozwalające na ich identyfikację zostały pominięte, jednakże wszystkie dane są autentyczne i pochodzą z bazy danych SWD - ST 2,5 prowadzonej i wykorzystywanej przez PSP.

Do analiz przyjęto jedną kategorię zdarzeń - pożary, nie klasyfikując ich ze względu na wielkość. Natomiast jako obszar podstawowy przyjęto obszar gminy. Wyniki analiz zestawiono w tabeli 5. Kolorem zaznaczono prognozy nietrafione.

$Z$ analizy danych w tabeli 5 wynika, że liczba prognoz nietrafionych dla gmin na poziomie ufności 0,95 wyniosła 53 przy 190 prognozach, co stanowi około $27 \%$. Natomiast na poziomie ufności 0,98 prognoz nietrafionych było 38 , co stanowi $20 \%$ wszystkich prognoz dla gmin. W przypadku powiatów błąd ten jest znacznie większy i wynosi 53\% (8 nietrafionych na 15 wszystkich).

Jeżeli jednak prognozy dla powiatów powstaną jako agregacja prognoz dla gmin, wówczas dla poziomu ufności 0,95 będzie 6 nietrafionych prognoz na 15, czyli $40 \%$. Natomiast dla poziomu ufności 0,98 jedynie 2 nietrafione prognozy na 15 , czyli 13\%. Należy ten fakt wyraźnie podkreślić, o czym pisano już wcześniej. Prognozowanie należy czynić dla małych obszarów podstawowych, a później dokonywać agregacji prognoz dla większych obszarów gmin i powiatów.

Na potwierdzenie tego faktu przeprowadzona została analiza w oparciu o obszary podstawowe wyznaczone liniami siatki topograficznej w Państwowym Układzie Współrzędnych Geodezyjnych 1992 dla gmin o największym współczynniku chybionych prognoz. $Z$ tabeli 5 wynika, że należą do nich gmina 12 i $17 \mathrm{z}$ powiatu III.

Tabela 5. Przestrzenna analiza ryzyka dla trzech powiatów (obszar podstawowy gmina)

Table 5. Spatial risk analysis for three districts (commune as a basic area )

\begin{tabular}{|c|c|c|c|c|c|c|c|c|c|c|c|c|c|c|c|c|}
\hline \multirow[b]{2}{*}{ 节 } & \multicolumn{3}{|c|}{2006} & \multicolumn{3}{|c|}{2007} & \multicolumn{3}{|c|}{2008} & \multicolumn{3}{|c|}{2009} & \multicolumn{3}{|c|}{2010} & \multirow[b]{2}{*}{ 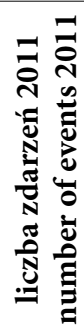 } \\
\hline & 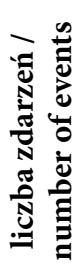 & 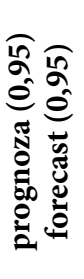 & 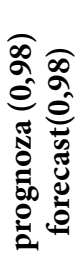 & 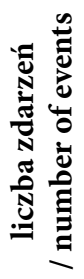 & 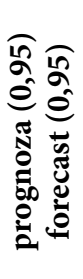 & 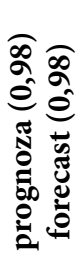 & 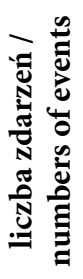 & 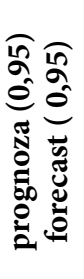 & 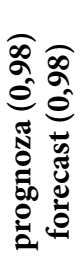 & 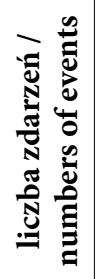 & 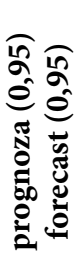 & 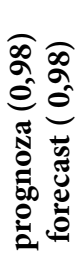 & 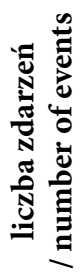 & 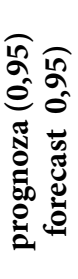 & 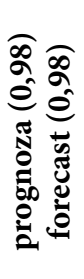 & \\
\hline \multicolumn{17}{|c|}{$\begin{array}{l}\text { Powiat I } \\
\text { District I }\end{array}$} \\
\hline 1 & 407 & 440 & 454 & 614 & 655 & 672 & 670 & 713 & 730 & 638 & 680 & 697 & 415 & 449 & 462 & 521 \\
\hline 2 & 22 & 30 & 33 & 14 & 20 & 23 & 17 & 24 & 27 & 14 & 20 & 23 & 19 & 26 & 29 & 13 \\
\hline 3 & 13 & 19 & 21 & 14 & 20 & 23 & 27 & 36 & 39 & 6 & 10 & 12 & 11 & 16 & 19 & 25 \\
\hline 4 & 13 & 19 & 21 & 13 & 19 & 21 & 26 & 34 & 38 & 30 & 39 & 43 & 15 & 21 & 24 & 17 \\
\hline 5 & 8 & 13 & 15 & 4 & 7 & 9 & 10 & 15 & 17 & 5 & 9 & 10 & 8 & 13 & 15 & 5 \\
\hline
\end{tabular}




\begin{tabular}{|c|c|c|c|c|c|c|c|c|c|c|c|c|c|c|c|c|}
\hline \multirow[b]{2}{*}{ 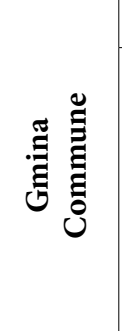 } & \multicolumn{3}{|c|}{2006} & \multicolumn{3}{|c|}{2007} & \multicolumn{3}{|c|}{2008} & \multicolumn{3}{|c|}{2009} & \multicolumn{3}{|c|}{2010} & \multirow[b]{2}{*}{ 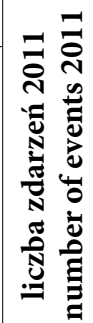 } \\
\hline & 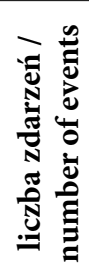 & 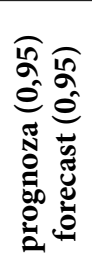 & 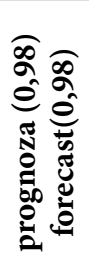 & 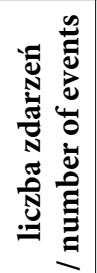 & 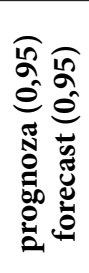 & 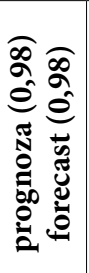 & 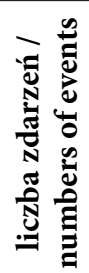 & 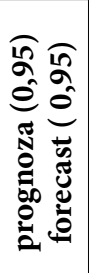 & 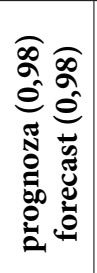 & 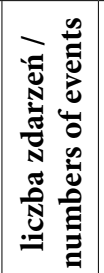 & 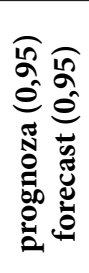 & 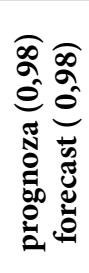 & 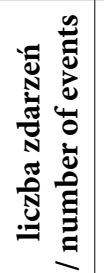 & 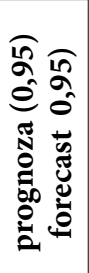 & 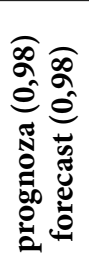 & \\
\hline 6 & 24 & 32 & 35 & 16 & 23 & 25 & 23 & 31 & 34 & 23 & 31 & 34 & 39 & 49 & 54 & 22 \\
\hline 7 & 28 & 37 & 40 & 22 & 30 & 33 & 47 & 58 & 63 & 39 & 49 & 54 & 24 & 32 & 35 & 26 \\
\hline 8 & 26 & 34 & 38 & 11 & 16 & 19 & 26 & 34 & 38 & 24 & 32 & 35 & 10 & 15 & 17 & 22 \\
\hline 9 & 12 & 18 & 20 & 17 & 24 & 27 & 25 & 33 & 37 & 30 & 39 & 43 & 6 & 10 & 12 & 12 \\
\hline 10 & 11 & 16 & 19 & 17 & 24 & 27 & 29 & 38 & 42 & 16 & 23 & 25 & 15 & 21 & 24 & 24 \\
\hline 11 & 15 & 21 & 24 & 11 & 16 & 19 & 21 & 29 & 32 & 19 & 26 & 29 & 18 & 25 & 28 & 13 \\
\hline 12 & 16 & 2 . & 25 & 13 & 19 & 21 & 19 & 26 & 29 & 10 & 15 & 17 & 4 & 7 & 9 & 19 \\
\hline 13 & 13 & 19 & 21 & 16 & 23 & 25 & 28 & 37 & 40 & 31 & 40 & 44 & 13 & 19 & 21 & 25 \\
\hline 14 & 19 & 26 & 29 & 21 & 29 & 32 & 29 & 38 & 42 & 38 & 48 & 52 & 19 & 26 & 29 & 24 \\
\hline 15 & 14 & 20 & 23 & 16 & 23 & 25 & 42 & 53 & 57 & 17 & 24 & 27 & 11 & 16 & 19 & 11 \\
\hline 16 & 29 & 3 & 42 & 19 & 26 & 29 & 18 & 25 & 28 & 26 & 34 & 38 & 14 & 20 & 23 & 17 \\
\hline $\begin{array}{l}\text { Razem / } \\
\text { Total }\end{array}$ & 670 & 713 & 730 & 838 & 886 & 905 & 1057 & 1110 & 1133 & 966 & 1017 & 1038 & 453 & 488 & 503 & 507 \\
\hline \multicolumn{17}{|c|}{$\begin{array}{l}\text { Powiat II } \\
\text { District II }\end{array}$} \\
\hline 1 & 118 & 136 & 143 & 113 & 130 & 138 & 96 & 112 & 119 & 139 & 158 & 166 & 82 & 97 & 103 & 87 \\
\hline 2 & 32 & 41 & 45 & 21 & 29 & 32 & 26 & 34 & 38 & 33 & 42 & 46 & 16 & 23 & 25 & 42 \\
\hline 3 & 72 & 86 & 92 & 48 & 59 & 64 & 55 & 67 & 72 & 103 & 120 & 127 & 46 & 57 & 62 & 72 \\
\hline 4 & 385 & 417 & 431 & 264 & 291 & 302 & 323 & 353 & 365 & 328 & 358 & 370 & 229 & 254 & 264 & 219 \\
\hline 5 & 66 & 79 & 85 & 87 & 102 & 109 & 52 & 64 & 69 & 77 & 91 & 97 & 80 & 95 & 101 & 87 \\
\hline $\begin{array}{l}\text { Razem / } \\
\text { Total }\end{array}$ & 673 & 716 & 733 & 533 & 571 & 587 & 552 & 591 & 607 & 680 & 723 & 741 & 453 & 488 & 503 & 507 \\
\hline \multicolumn{17}{|c|}{$\begin{array}{l}\text { Powiat III } \\
\text { District III }\end{array}$} \\
\hline 1 & 315 & 344 & 356 & 313 & 342 & 354 & 314 & 343 & 355 & 260 & 287 & 298 & 292 & 320 & 332 & 253 \\
\hline 2 & 42 & 53 & 57 & 54 & 66 & 71 & 48 & 59 & 64 & 44 & 55 & 59 & 61 & 74 & 79 & 79 \\
\hline 3 & 19 & 26 & 29 & 16 & 23 & 25 & 4 & - & 9 & 7 & 11 & 13 & 13 & 19 & 21 & 10 \\
\hline 4 & 2 & 4 & 5 & 6 & 10 & 12 & 9 & 14 & 16 & 12 & 18 & 20 & 15 & 21 & 24 & 16 \\
\hline 5 & 29 & 38 & 42 & 24 & 32 & 35 & 28 & 37 & 40 & 21 & 29 & 32 & 40 & 50 & 55 & 43 \\
\hline 6 & 8 & 1 & 15 & 10 & 1 & 17 & 4 & 7 & 9 & 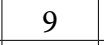 & 14 & 16 & 12 & 18 & 20 & 14 \\
\hline 7 & 9 & 1 & 16 & 8 & 10 & 15 & 6 & 10 & 12 & 10 & 15 & 17 & 10 & 15 & 17 & 11 \\
\hline 8 & 37 & 4 & 51 & 48 & 59 & 64 & 34 & 44 & 48 & 39 & 49 & 54 & 46 & 57 & 62 & 38 \\
\hline 9 & 7 & 1 & 13 & 7 & 11 & 13 & 2 & 6 & 7 & 6 & 10 & 12 & 13 & 19 & 21 & 3 \\
\hline 10 & 14 & 20 & 23 & 31 & 40 & 44 & 31 & 40 & 44 & 24 & 32 & 35 & 45 & 56 & 61 & 55 \\
\hline 11 & 12 & 18 & 20 & 12 & 18 & 20 & 6 & 10 & 12 & 10 & 15 & 17 & 9 & 14 & 16 & 14 \\
\hline 12 & 23 & 31 & 34 & 52 & 64 & 69 & 51 & 63 & 68 & 69 & 83 & 88 & 96 & 112 & 119 & 70 \\
\hline 13 & 13 & 15 & 21 & 7 & 11 & 13 & 13 & 19 & 21 & 11 & 16 & 19 & 18 & 25 & 28 & 11 \\
\hline 14 & 69 & 8 & 88 & 136 & 155 & 163 & 70 & 84 & 89 & - & 63 & 68 & 75 & 89 & 95 & 87 \\
\hline 15 & 15 & 21 & 24 & 24 & 32 & 35 & 10 & 15 & 17 & 13 & 19 & 21 & 19 & 26 & 29 & 46 \\
\hline 16 & 28 & 3 & 40 & $\sqrt{2}$ & 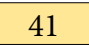 & $4 J$ & & 34 & Jo & 10 & 30 & 61 & 60 & 73 & 78 & 44 \\
\hline 17 & 54 & 66 & 71 & 108 & 125 & 132 & 85 & 100 & 106 & 81 & 96 & 102 & 104 & 121 & 128 & 147 \\
\hline $\begin{array}{l}\text { Razem / } \\
\text { Total }\end{array}$ & 696 & 739 & 757 & 888 & 937 & 957 & 759 & 804 & 823 & 712 & 756 & 774 & 928 & 978 & 999 & 941 \\
\hline
\end{tabular}

Źródło: Opracowanie własne

Source: Own elaboration.

$\mathrm{Z}$ analizy przestrzennej zagrożeń zawartej w tabeli 6 wynika, że w przypadku gminy $12 \mathrm{z}$ powiatu III tylko jedna prognoza była nietrafiona przy poziomie ufności 0,95, co wskazuje na 80-procentową skuteczność. Przy poziomie ufności 0,98 wszystkie prognozy były trafione.
Nadmiarowość prognozowania kształtowała się na różnym poziomie. W rozliczeniu 5-letnim wyniosła ona dla poziomu ufności 0,95 - 42\% (prognozowano około $42 \%$ zdarzeń więcej). Natomiast dla poziomu ufności 0,98 zaprognozowano około $60 \%$ więcej zdarzeń. 
Tabela 6. Przestrzenna analiza ryzyka dla gminy 12 powiatu III (obszar podstawowy $1 \mathrm{~km}$ )

Table 6. Spatial risk analysis for commune 12 district III (1 km as a basic area)

\begin{tabular}{|c|c|c|c|c|c|c|c|c|c|c|c|c|c|c|c|c|}
\hline \multirow[b]{2}{*}{ 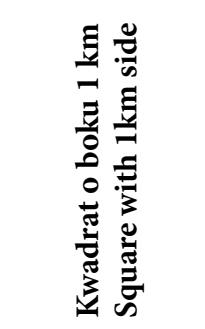 } & \multicolumn{3}{|c|}{2006} & \multicolumn{3}{|c|}{2007} & \multicolumn{3}{|c|}{2008} & \multicolumn{3}{|c|}{2009} & \multicolumn{3}{|c|}{2010} & \multirow[b]{2}{*}{ 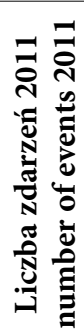 } \\
\hline & 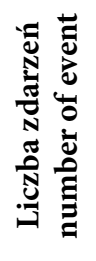 & 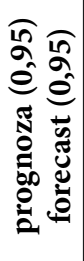 & 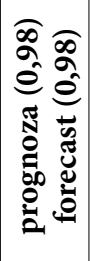 & 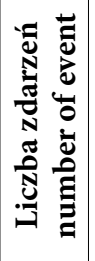 & 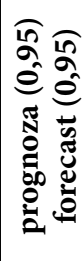 & 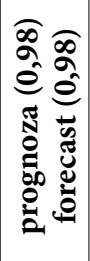 & 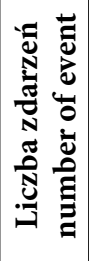 & 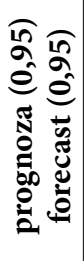 & 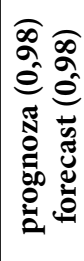 & 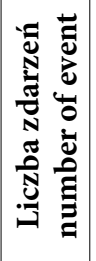 & 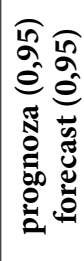 & 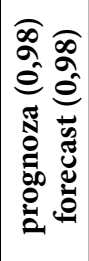 & 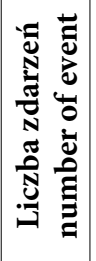 & 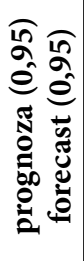 & 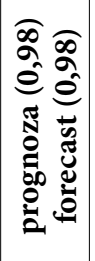 & \\
\hline 1 & & & & 3 & 6 & 7 & 7 & 11 & 13 & 3 & 6 & 7 & 2 & 4 & 5 & 1 \\
\hline 2 & 1 & 3 & 3 & & & & & & & & & & & & & \\
\hline 3 & & & & 1 & 3 & 3 & 5 & 9 & 10 & 3 & 6 & 7 & 9 & 14 & 16 & 14 \\
\hline 4 & 1 & 3 & 3 & 3 & 6 & 7 & & & & & & & & & & \\
\hline 5 & & & & 2 & 4 & 5 & & & & & & & 1 & 3 & 3 & \\
\hline 6 & 1 & 3 & 3 & & & & & & & & & & & & & \\
\hline 7 & & & & 1 & 3 & 3 & & & & 2 & 4 & 5 & 1 & 3 & 3 & \\
\hline 8 & & & & 2 & 4 & 5 & 1 & 3 & 3 & 2 & 4 & 5 & 3 & 6 & 7 & 3 \\
\hline 9 & & & & 1 & 3 & 3 & & & & & & & & & & \\
\hline 10 & & & & 1 & 3 & 3 & & & & & & & & & & \\
\hline 11 & 1 & 3 & 3 & 15 & 21 & 24 & 28 & 37 & 40 & 34 & 44 & 48 & 51 & 63 & 68 & 35 \\
\hline 12 & 6 & 10 & 12 & 4 & 7 & 9 & & & & & & & & & & \\
\hline 13 & & & & 1 & 3 & 3 & & & & 3 & 6 & 7 & 2 & 4 & 5 & 3 \\
\hline 14 & 1 & 3 & 3 & & & & & & & & & & & & & \\
\hline 15 & 1 & 3 & 3 & & & & & & & & & & & & & \\
\hline 16 & 4 & 7 & 9 & 5 & 9 & 10 & & & & & & & & & & \\
\hline 17 & 1 & 3 & 3 & & & & & & & & & & & & & \\
\hline 18 & 1 & 3 & 3 & 1 & 3 & 3 & 1 & 3 & 3 & 1 & 3 & 3 & 2 & 4 & 5 & 1 \\
\hline 19 & & & & 1 & 3 & 3 & 5 & 9 & 10 & 6 & 10 & 12 & 7 & 11 & 13 & 4 \\
\hline 20 & & & & & & & 2 & 4 & 5 & 4 & 7 & 9 & 11 & 16 & 19 & 8 \\
\hline 21 & & & & 1 & 3 & 3 & & & & & & & & & & \\
\hline 22 & & & & 5 & 9 & 10 & 2 & 4 & 5 & 10 & 15 & 17 & 6 & 10 & 12 & 1 \\
\hline 23 & 4 & 7 & 9 & 4 & 7 & 9 & & & & & & & & & & \\
\hline 24 & & & & 1 & 3 & 3 & & & & 1 & 3 & 3 & & & & \\
\hline 25 & 1 & 3 & 3 & & & & & & & & & & & & & \\
\hline 26 & & & & & & & & & & & & & 1 & 3 & 3 & \\
\hline $\begin{array}{l}\text { Gmina } \\
\text { Commune }\end{array}$ & 23 & 51 & 57 & 52 & 100 & 113 & 51 & 80 & 89 & 69 & 108 & 123 & 96 & 141 & 159 & 70 \\
\hline $\begin{array}{l}\text { nadmiarowość } \\
\text { prognozy } \\
\text { forecast } \\
\text { redundancy }\end{array}$ & & -1 & 5 & & 49 & 62 & & 11 & 20 & & 12 & 27 & & 71 & 89 & \\
\hline
\end{tabular}

Źródło: Opracowanie własne.

Source: Own elaboration.

Przestrzenna analiza zagrożeń oparta na obszarach podstawowych o powierzchni $1 \mathrm{~km}^{2}$ (obszary wyznaczone przez linie siatki topograficznej w Państwowym Układzie Współrzędnych geodezyjnych 1992) dla gminy 17 powiatu
III zawarta w tabeli 7. wskazuje na 100-procentową skuteczność prognoz dla gminy. Nadmiarowość prognoz wynosi odpowiednio w rozliczeniu 5-letnim $60 \%$ (poziom ufności 0,95 ) oraz $80 \%$ (poziom ufności 0,98 ). 
Tabela 7. Przestrzenna analiza ryzyka dla gminy 17 powiatu III (obszar podstawowy $1 \mathrm{~km}$ )

Table. 7. Spatial risk analysis for commune 17 district county III (base area $1 \mathrm{~km}$ )

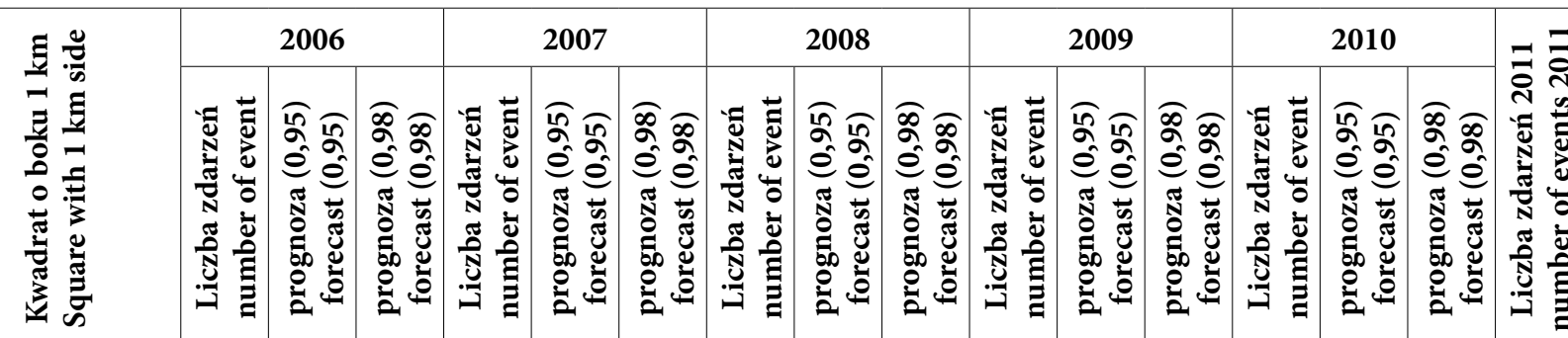

\begin{tabular}{|c|c|c|c|c|c|c|c|c|c|c|c|c|c|c|c|c|}
\hline 1 & 1 & 3 & 3 & & & & & & & & & & & & & \\
\hline 2 & & & & 1 & 3 & 3 & & & & & & & & & & \\
\hline 3 & & & & & & & 5 & 9 & 10 & 1 & 3 & 3 & 1 & 3 & 3 & 1 \\
\hline 4 & 1 & 3 & 3 & & & & & & & & & & & & & \\
\hline 5 & & & & 1 & 3 & 3 & & & & & & & & & & \\
\hline 6 & & & & 1 & 3 & 3 & & & & & & & & & & \\
\hline 7 & 1 & 3 & 3 & & & & & & & & & & & & & \\
\hline 8 & 2 & 4 & 5 & & & & & & & & & & & & & \\
\hline 9 & & & & 2 & 4 & 5 & 2 & 4 & 5 & 1 & 3 & 3 & 4 & 7 & 9 & 4 \\
\hline 10 & & & & 1 & 3 & 3 & & & & & & & & & & \\
\hline 11 & 1 & 3 & 3 & & & & & & & & & & & & & \\
\hline 12 & 1 & 3 & 3 & 2 & 4 & 5 & & & & & & & & & & \\
\hline 13 & & & & & & & 2 & 4 & 5 & 1 & 3 & 3 & & & & 1 \\
\hline 14 & 2 & 4 & 5 & 1 & 3 & 3 & 1 & 3 & 3 & 2 & 4 & 5 & 3 & 6 & 7 & 3 \\
\hline 15 & & & & 3 & 6 & 7 & & & & 3 & 6 & 7 & 1 & 3 & 3 & \\
\hline 16 & 1 & 3 & 3 & 1 & 3 & 3 & & & & & & & & & & \\
\hline 17 & 1 & 3 & 3 & & & & & & & & & & & & & \\
\hline 18 & 1 & 3 & 3 & 1 & 3 & 3 & & & & & & & & & & \\
\hline 19 & & & & 3 & 6 & 7 & & & & & & & & & & \\
\hline 20 & & & & 4 & 7 & 9 & 1 & 3 & 3 & 4 & 7 & 9 & 2 & 4 & 5 & 2 \\
\hline 21 & 2 & 4 & 5 & 4 & 7 & 9 & & & & & & & 2 & 4 & 5 & 4 \\
\hline 22 & 2 & 4 & 5 & 1 & 3 & 3 & & & & & & & & & & \\
\hline 23 & 4 & 7 & 9 & 2 & 4 & 5 & & & & & & & & & & \\
\hline 24 & 7 & 11 & 13 & 4 & 7 & 9 & & & & & & & & & & \\
\hline 25 & 1 & 3 & 3 & 1 & 3 & 3 & & & & & & & & & & \\
\hline 26 & & & & 11 & 16 & 19 & 28 & 37 & 40 & 37 & 47 & 51 & 47 & 58 & 63 & 68 \\
\hline 27 & 1 & 3 & 3 & & & & & & & & & & & & & \\
\hline 28 & & & & 1 & 3 & 3 & & & & & & & & & & \\
\hline 29 & & & & 3 & 6 & 7 & & & & & & & & & & \\
\hline 30 & 1 & 3 & 3 & 8 & 13 & 15 & & & & & & & & & & \\
\hline 31 & 3 & 6 & 7 & 3 & 6 & 7 & & & & & & & & & & \\
\hline 32 & & & & 1 & 3 & 3 & & & & & & & & & & \\
\hline 33 & 1 & 3 & 3 & 3 & 6 & 7 & & & & & & & & & & \\
\hline 34 & 7 & 11 & 13 & 7 & 11 & 13 & 5 & 9 & 10 & 3 & 6 & 7 & 22 & 30 & 33 & 34 \\
\hline 35 & 1 & 3 & 3 & 4 & 7 & 9 & 5 & 9 & 10 & 11 & 16 & 19 & 8 & 13 & 15 & 4 \\
\hline 36 & 2 & 4 & 5 & & & & 1 & 3 & 3 & & & & & & & \\
\hline 37 & & & & & & & 1 & 3 & 3 & & & & & & & \\
\hline 38 & 1 & 3 & 3 & 1 & 3 & 3 & & & & & & & & & & \\
\hline 39 & 1 & 3 & 3 & & & & & & & & & & & & & \\
\hline 40 & 1 & 3 & 3 & & & & & & & & & & & & & \\
\hline 41 & & & & 1 & 3 & 3 & & & & & & & & & & \\
\hline 42 & & & & 1 & 3 & 3 & & & & & & & & & & \\
\hline 43 & & & & 3 & 6 & 7 & & & & 1 & 3 & 3 & & & & 2 \\
\hline 44 & 1 & 3 & 3 & 4 & 7 & 9 & & & & & & & & & & \\
\hline 45 & 1 & 3 & 3 & 1 & 3 & 3 & & & & & & & & & & \\
\hline 46 & 2 & 4 & 5 & 2 & 4 & 5 & & & & & & & & & & \\
\hline
\end{tabular}




\begin{tabular}{|c|c|c|c|c|c|c|c|c|c|c|c|c|c|c|c|c|}
\hline \multirow{2}{*}{ 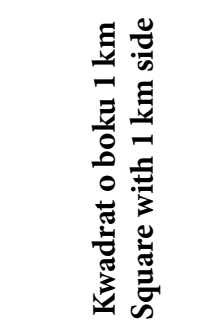 } & \multicolumn{3}{|c|}{2006} & \multicolumn{3}{|c|}{2007} & \multicolumn{3}{|c|}{2008} & \multicolumn{3}{|c|}{2009} & \multicolumn{3}{|c|}{2010} & \multirow{2}{*}{ 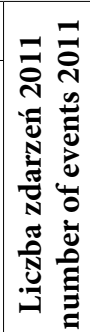 } \\
\hline & 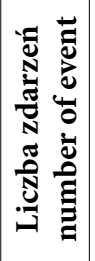 & 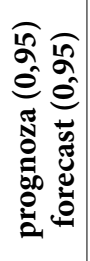 & 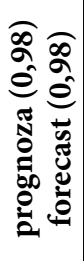 & 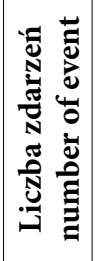 & 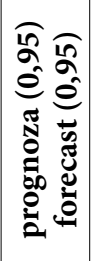 & 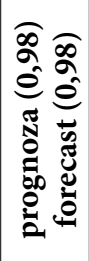 & 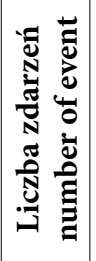 & 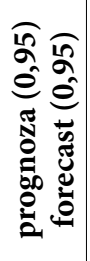 & 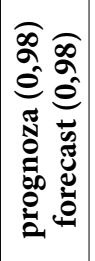 & 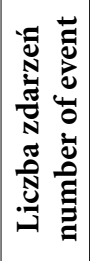 & 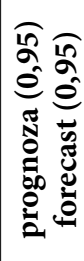 & 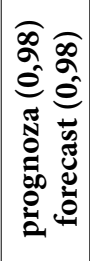 & 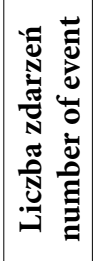 & 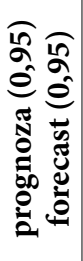 & 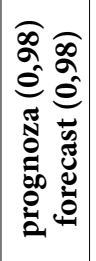 & \\
\hline 47 & 1 & 3 & 3 & & & & & & & & & & & & & \\
\hline 48 & & & & & & & 1 & 3 & 3 & & & & & & & \\
\hline 49 & & & & 1 & 3 & 3 & & & & & & & & & & \\
\hline 50 & 2 & 4 & 5 & 5 & 9 & 10 & 5 & 9 & 10 & 6 & 10 & 12 & 3 & 6 & 7 & 3 \\
\hline 51 & & & & 2 & 4 & 5 & 1 & 3 & 3 & & & & 2 & 4 & 5 & 3 \\
\hline 52 & & & & 10 & 15 & 17 & 22 & 30 & 33 & 9 & 14 & 16 & 7 & 11 & 13 & 10 \\
\hline 53 & & & & 1 & 3 & 3 & & & & & & & & & & \\
\hline 54 & & & & 1 & 3 & 3 & & & & & & & & & & \\
\hline 55 & & & & & & & 3 & 6 & 7 & 1 & 3 & 3 & 1 & 3 & 3 & 7 \\
\hline 56 & & & & & & & 2 & 4 & 5 & 1 & 3 & 3 & 1 & 3 & 3 & \\
\hline 57 & & & & 1 & 3 & 3 & & & & & & & & & & \\
\hline 58 & & & & & & & & & & & & & & & & 1 \\
\hline Razem / Total & 54 & 120 & 134 & 108 & 212 & 243 & 85 & 139 & 153 & 81 & 128 & 144 & 104 & 155 & 174 & 147 \\
\hline $\begin{array}{l}\text { nadmiarowość } \\
\text { prognozy / } \\
\text { forecast } \\
\text { redundancy }\end{array}$ & & 12 & 26 & & 127 & 158 & & 58 & 72 & & 24 & 40 & & 8 & 27 & \\
\hline
\end{tabular}

Źródło: Opracowanie własne.

Source: Own elaboration.

Należy równocześnie wskazać, że w rozliczeniu rocznym najmniejsza nadmiarowość prognozy wynosi zaledwie 5\%. Wynika to $\mathrm{z}$ faktu, iż w gminach tych (12 i 17) dostrzegamy dużą dynamikę liczby zdarzeń krytycznych w kolejnych latach. Zmiana liczby zdarzeń z roku na rok dla tych gmin wynosi nawet $100 \%$. Przy większej stabilności liczby zdarzeń krytycznych nadmiarowość prognozowania będzie mniejsza.

Bardziej szczegółowa analiza wskazuje również pewne tendencje, np. obszar 26 gminy 17 (tabela 7) wskazuje na znaczny przyrost pożarów z roku na rok. Poczynając od 2007 roku, w którym było na tym obszarze 11 pożarów, dostrzegamy wzrost tych zdarzeń do liczby 68 w roku 2011. Liczba pożarów w tym kwadracie wzrosła w ciągu 5 lat 6-cio krotnie.

Reasumując, wiarygodność prognoz rośnie wraz ze zmniejszaniem obszaru podstawowego, dla którego dokonujemy prognozy. Wielkość tego obszaru nie powinna być jednak mniejsza niż $1 \mathrm{~km}^{2}$. Najwyższą wiarygodność prognoz dla powiatu i gminy uzyskujemy przez agregację prognoz dla obszarów podstawowych.

\section{Podsumowanie}

Przestrzenna analiza zagrożeń pozwala na ujawnienie obszarów o zwiększonej częstości zdarzeń krytycznych oraz tendencje w dynamice zmian ich występowania. Daje również możliwość prognozowania (w niewielkiej perspektywie czasowej) przyszłego przestrzennego rozmieszczenia miejsc powstawania incydentów krytycznych. Możliwość prognozowania daje silna zbieżność rozkładów empirycznych pojawiania się kolejnych zdarzeń krytycznych $\mathrm{z}$ teoretycznym rozkładem wykładniczym. Proces pojawiania się kolejnych zdarzeń krytycznych można opisać stacjonarnym procesem Poissona o oczekiwanej liczbie zdarzeń równej liczbie zdarzeń z poprzedniego okresu obserwacji.

Wysoką wiarygodność prognoz uzyskuje się przez agregację prognoz dla obszarów podstawowych - obszarów o powierzchni $1 \mathrm{~km}^{2}$ wyznaczonych przez linie siatki topograficznej.

Artykuł został opracowany w ramach projektu nr DOBR/0015/R/ID1/2012/03 pt. „Zaawansowane technologie teleinformatyczne wspomagające projektowanie systemu ratowniczego na poziomach: gmina, powiat, województwo" realizowanego przez konsorcjum naukowe ze środków finansowych Narodowego Centrum Badań i Rozwoju (konkurs nr 3/2012 na wykonanie projektów w zakresie badań naukowych lub prac rozwojowych na rzecz obronności i bezpieczeństwa państwa). 


\section{Literatura}

[1] Ciocchetta F., Gilmore S., Guerriero M. L., Hillston J., Integrated Simulation and Model-Checking for the Analysis of Biochemical Systems, "Electronic Notes in Theoretical Computer Science" Vol. 232, 2009, p. 17-38.

[2] Guerriero V., Iannace A., Mazzoli S., Parente M., Vitale S., Giorgioni M., Quantifying uncertainties in multi-scale studies of fractured reservoir analogues: Implemented statistical analysis of scan line data from carbonate rocks, „Journal of Structural Geology”, 2009.

[3] Koronacki J., Mielniczuk J., Statystyka dla studentów kierunków technicznych i przyrodniczych, WNT, Warszawa 2006
[4] Prońko J., Bezpieczeństwo, zagrożenie, kryzys w kontekście kierowania organizacjami, AON, Warszawa 2011.

[5] Prońko J., Zarzadzanie ryzykiem w obszarze bezpieczeństwa powszechnego, Wyższa Szkoła Administracji, Bielsko-Biała 2010.

[6] Reducing risks, protecting people. HSE's decision - making process, Her Majesty's Stationery Office, HSE, Norwich 2001.

[7] Evans Ronald J., Boersma J., Blachman N.M., Jagers A.A., The Entropy of a Poisson Distribution: Problem 87-6, "SIAM Review” Vol. 30 Issue, 1988, pp. 314-317

[8] Wawrzynek J., Metody opisu i wnioskowania statystycznego, Wydawnictwo Akademii Ekonomicznej im. Oskara Langego we Wrocławiu, Wrocław 2007.

dr hab. inż. Jarosław Prońko - profesor nadzwyczajny Instytutu Zarządzania Uniwersytetu Jana Kochanowskiego w Kielcach. Absolwent Politechniki Świętokrzyskiej i AON. Były oficer Nadwiślańskich Jednostek Wojskowych. Uczestnik akcji przeciwpowodziowej w 1997 r. - odznaczony Krzyżem Zasługi za Dzielność. W latach 1998-2001, główny specjalista w Biurze Spraw Obronnych MSWiA. Autor i współautor wielu prac z zakresu bezpieczeństwa powszechnego, zarządzania kryzysowego, problematyki podejmowania decyzji oraz analizy ryzyka w obszarze bezpieczeństwa powszechnego.

st. bryg. w st. sp. mgr inż. Jan Kielin - w 1968 r. ukończył Szkołę Oficerów Pożarnictwa w Warszawie, a w 1977 r. Wyższą Oficerską Szkołę Pożarniczą w Warszawie. W latach 1981-1983 odbył studia magisterskie w Wyższej Szkole Pedagogicznej w Krakowie. W roku 1975 uzyskał uprawnienia rzeczoznawcy do spraw zabezpieczeń przeciwpożarowych. Autor wielu publikacji z zakresu bezpieczeństwa pożarowego (m.in. Poradnik dla Specjalisty Ochrony Przeciwpożarowej, Materiały szkoleniowe dla pracowników zakładów pracy) oraz tłumaczeń (z j. niemieckiego) z zakresu ochrony przeciwpożarowej.

mgr Beata Wojtasiak - absolwentka Akademii Pedagogiki Specjalnej im. Marii Grzegorzewskiej w Warszawie (Wydział Nauk Pedagogicznych). W 2013 r. ukończyła studia podyplomowe Menedżer Innowacji w Szkole Głównej Handlowej w Warszawie. Aktualnie pracownik Jednostki Certyfikującej Centrum Naukowo-Badawczego Ochrony Przeciwpożarowej - Państwowego Instytutu Badawczego na stanowisku mł. specjalista inżynieryjno-techniczny. 